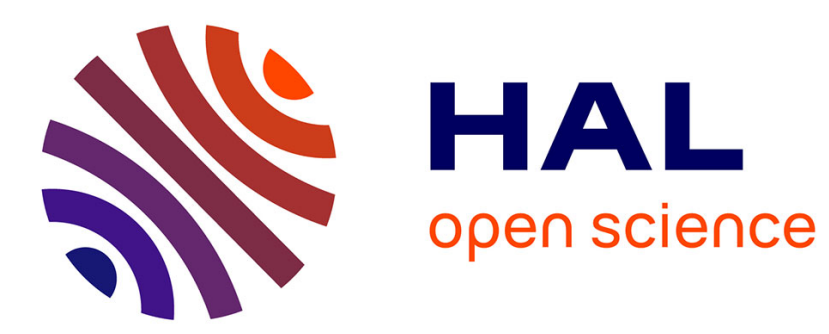

\title{
Synthesis and Properties of Furan Derivatives for Epoxy Resins
}

\author{
Nadim Eid, Bruno Ameduri, Bernard Boutevin
}

\section{To cite this version:}

Nadim Eid, Bruno Ameduri, Bernard Boutevin. Synthesis and Properties of Furan Derivatives for Epoxy Resins. ACS Sustainable Chemistry \& Engineering, 2021, 9 (24), pp.8018-8031. 10.1021/acssuschemeng.0c09313 . hal-03265663

\section{HAL Id: hal-03265663 https://hal.science/hal-03265663}

Submitted on 21 Jun 2021

HAL is a multi-disciplinary open access archive for the deposit and dissemination of scientific research documents, whether they are published or not. The documents may come from teaching and research institutions in France or abroad, or from public or private research centers.
L'archive ouverte pluridisciplinaire HAL, est destinée au dépôt et à la diffusion de documents scientifiques de niveau recherche, publiés ou non, émanant des établissements d'enseignement et de recherche français ou étrangers, des laboratoires publics ou privés. 


\title{
SYNTHESIS AND PROPERTIES OF FURAN DERIVATIVES FOR EPOXY RESINS ${ }^{\S}$
}

\author{
Nadim EID,${ }^{ \pm}$Bruno AMEDURI, ${ }^{ \pm} *$ Bernard BOUTEVIN ${ }^{ \pm}$ \\ ICGM, Univ. Montpellier, CNRS, ENSCM, 34000 Montpellier, France
}

Corresponding author: B. Ameduri (bruno.ameduri@enscm.fr)

\section{$\underline{\text { Abstract }}$}

The discovery of huge petroleum reserves in the 19th century was a golden opportunity that promoted the industrial revolution, by offering a wide variety of cheap raw materials and a reliable source of energy. This caused an unprecedented increase of commodity and production of specialty chemicals in order to fulfill the needs of the global markets. However, as the global warming and the environmental issues has become a hazardous and worried situation, researchers are looking for bio renewable monomers with low toxicity in order to produce more sustainable polymers. This policy was also applied to epoxy resin materials because of their high volume production in industry for a wide range of applications. This review highlights the recent advances in the preparation of diamines and diepoxy monomers for the synthesis of epoxy resins, mainly from 2-furfural, 5-(hydroxymethyl)furfural (5-HMF), and 2,5-furandicarboxylic acid (FDCA), obtained from natural cellulose and hemicellulose feedstocks, respectively, and able to replace phthalic moieties in polyethylene terephthalate. In addition, the processes involved in the monomers preparation, such as reductive amination, etherification, esterification and carbonatation are listed. This review, reporting quasi-exhaustive synthetic pathways of epoxy precursors containing furanic moieties and describing the resulting resins, is composed of seven main parts, based on the synthesis of glycidyl derivatives containing one or two or four furan nuclei bearing or not a spacer between the furan ring and the function. The influence of the substituents on furan moieties $\left(\mathrm{O}, \mathrm{CO}, \mathrm{CH}_{2}\right)$ and the spacer between these groups have also been evaluated. Finally, thermal and a few mechanical properties of the obtained bio-sourced epoxy resins were compared to their fossil fuel analogues (from bisphenol A), featuring the high potential of bio-based monomers as substituents for non-renewable ones.

Keywords: biomass; epoxy; furan; 2,5-furandicarboxylic acid; 5-hydroxymethyl furfural; telechelic; thermosets.

${ }^{\S}$ In memory of Dr Christian COLLETTE, Head of R\&D Arkema 


\section{INTRODUCTION}

Because of their attractive properties, ${ }^{1}$ epoxy resins have widely been involved in many applications including coatings, ${ }^{2}$ composites, ${ }^{3}$ electronic devices ${ }^{4}$ and as thermosets in aerospace industries. ${ }^{5}$ About $90 \%$ of epoxy resins are produced from fossil-based bisphenol A (BPA), named diglycidyl ether of bisphenol A (DGEBA). ${ }^{6}$ However, $10 \%$ were synthesized from renewable resources, ${ }^{7,8}$ the overall production has reached almost 3 million tons per year. ${ }^{9}$ In addition, DGEBA, is obtained from BPA and epichlorhydrine which are considered as carcinogenic, mutagenic, reprotoxic and as endocrine disruptors. ${ }^{10-13}$ Consequently, many researchers have been launched in order to obtain original non-toxic substitutes for epoxy resins in petro-compounds as well as in biobased derivatives. ${ }^{8,14} \mathrm{~A}$ comprehensive review article that describes all kinds of reactants was reported by Chen et al. ${ }^{15}$ Actually, many issues have been highlighted on BPA, ${ }^{16,17}$ that can form a close attachment to estrogen receptors ${ }^{18}$ and affect body functions as cell regeneration, ${ }^{19}$ embryo development, ${ }^{20}$ and also induces hormone-dependent tumors that may result in prostate or breast cancers. ${ }^{21}$ Thus, BPA containing substances have been prohibited in food packaging industries because of its leaching to the aliments, leading to human exposure to this harmful chemical. ${ }^{22}$ To remediate it, it is crucial to find out major resources from nature such as cellulose, polysaccharides, and fatty oils. ${ }^{23-27}$ The last ones afforded materials with low glass transition temperatures ( $\mathrm{Tg}),{ }^{28,29}$ and thus aromatic moieties, obtained from lignin, or pseudo-aromatic ones, afforded from hemicelluloses, are preferred due to the high physico-chemical properties induced by the presence of a rigid segment in the polymeric chain. ${ }^{30-32}$ Actually, such above natural polymers, cellulose and hemicelluloses (Scheme 1), lead to glucose ${ }^{33-35}$ and xylose, ${ }^{36}$ and can further generate 5-hydroxymethyl furfural $(\mathrm{HMF})^{37-40}$ and 2-furfural ${ }^{41-46}$ 


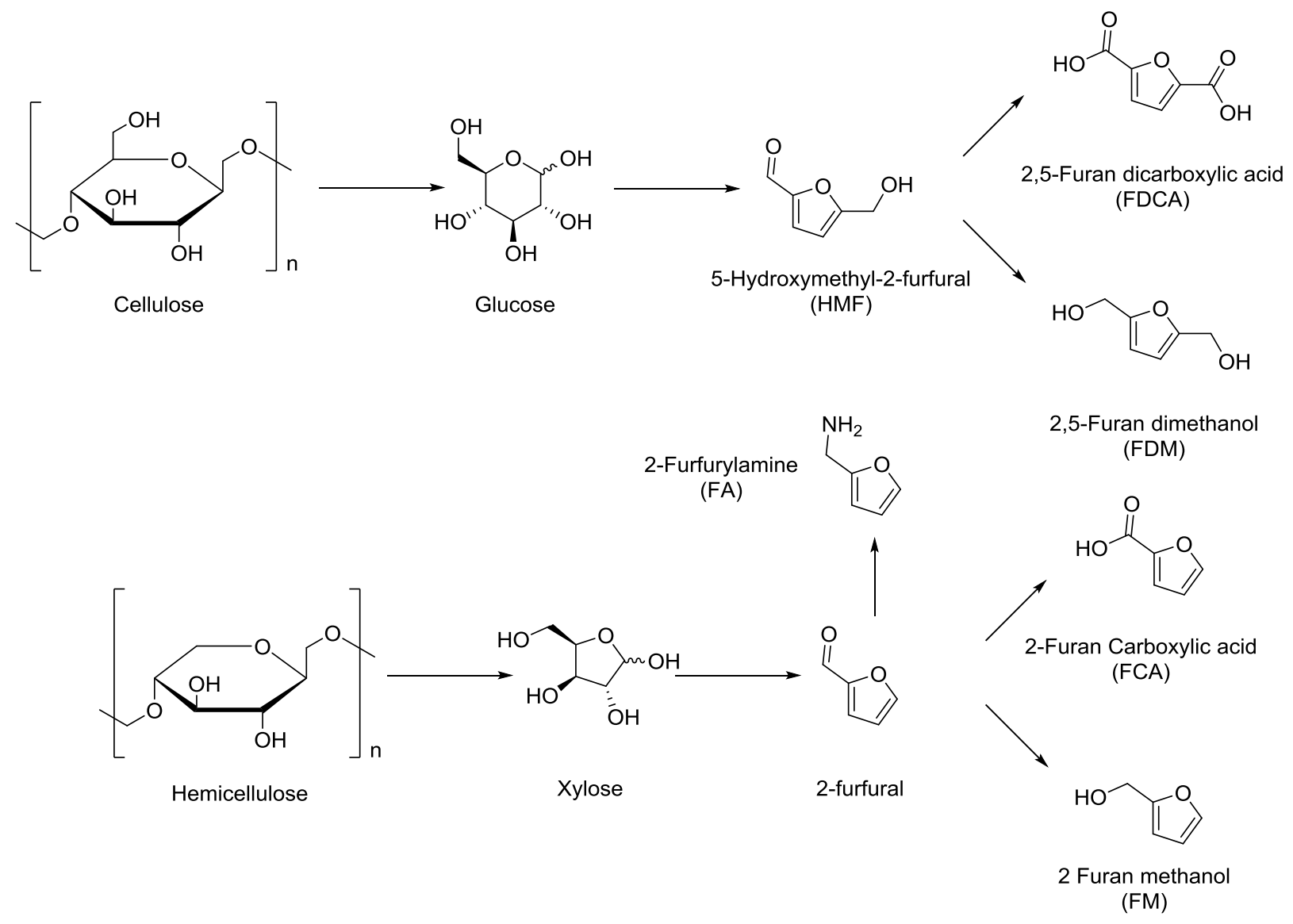

Scheme 1: Preparation of furanoic acids, aldehydes and alcohols from cellulose and hemicellulose ${ }^{46}$

Furfural $^{41-47}$ is monofunctional and has been involved in various applications related to energy (new fuels) and original solvents in contrast to HMF that is telechelic, and thus, can be utilized in many strategies involving the synthesis of epoxy resins and reactions opening the way to a wide variety of polymers ${ }^{47}$. Nevertheless, furfural is an interesting compound (Scheme 2) and several reviews report the main needs of chemistry (see below). ${ }^{44,45,47}$ 


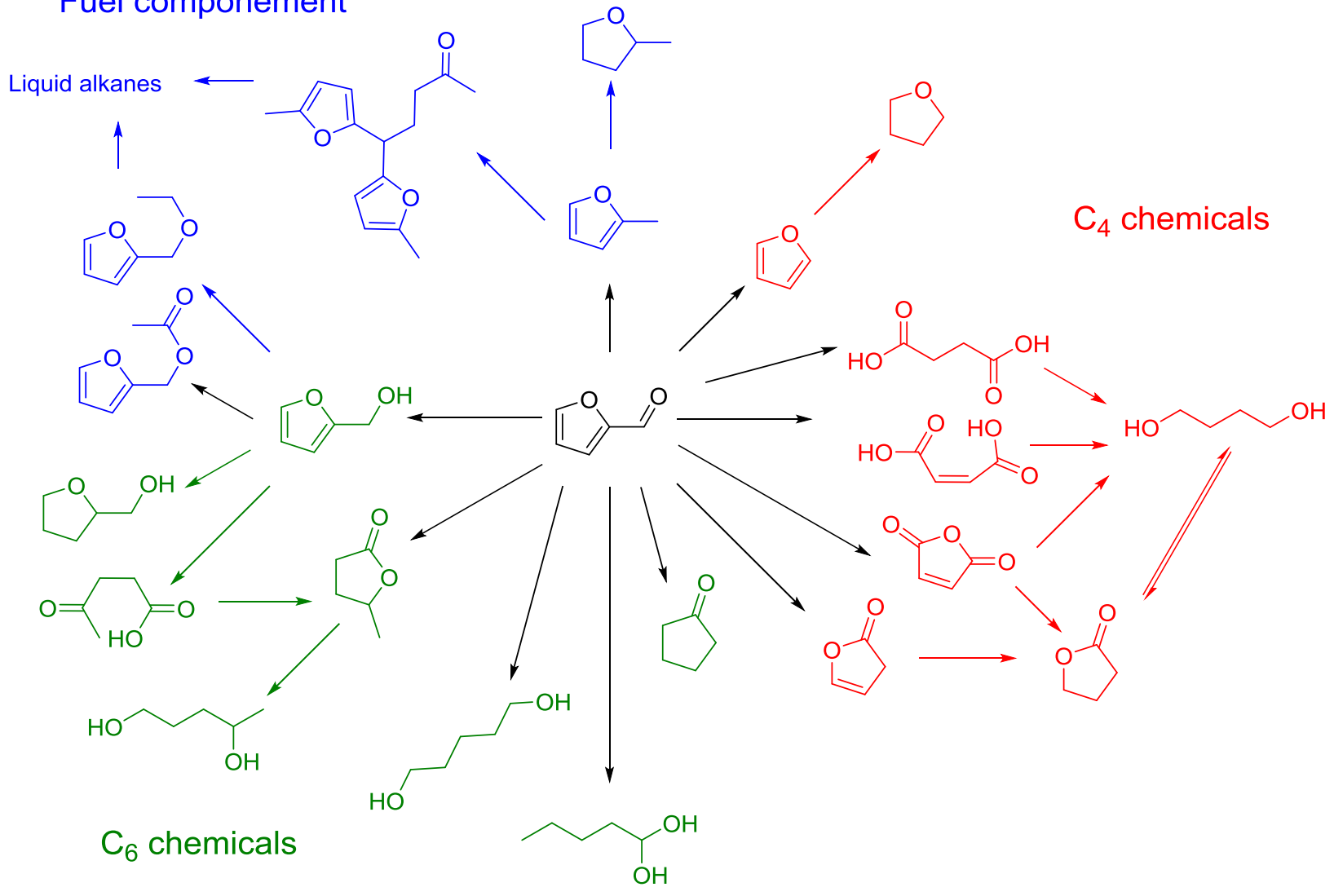

Scheme 2: Catalytic conversion of furfural to fuel components and synthons ${ }^{.47}$

Regarding HMF, as the specific goal of that present review, Zhang and Dumont ${ }^{48}$ reported a comprehensive update highlighting the different sources of furanoic products (Scheme 3). This state-of-the-art deals with the synthesis of all types of polymers (polyesters, polyurethanes, polyacrylics, cyanate resins, etc).

But, HMF is undergoing many issues which prevent it from commercialization: first, HMF is a hydrophilic and polar molecule that is hardly extracted from aqueous media. Polar aprotic solvents aqueous phase modifiers or ionic liquids have been potential alternatives but these candidates show cost, toxicity, stability, and recyclability limitations, as well as catalyst recovery. ${ }^{49}$ Second, HMF is sensitive to acid conditions (the medium in which it is produced) yielding humic matter and by-products. ${ }^{50,51}$ Furthermore, high yield-production of HMF lies on fructose as a feedstock, although use of glucose or sucrose in presence of catalysts have already led to interesting solvents, ${ }^{52,53}$ none of these sugars will ever be competitive with raw cellulosic biomass for a commercial production of HMF. ${ }^{54-56}$

However, to the best of our knowledge, no review dealing with the synthesis of epoxy compounds starting from furan and HMF derivatives has been reported yet, that is the aim of this present review. 
Several of the works outlined reflect studies in progress, or recently finalized ones, and thus are reported for the first time. Others were published in the last several years.

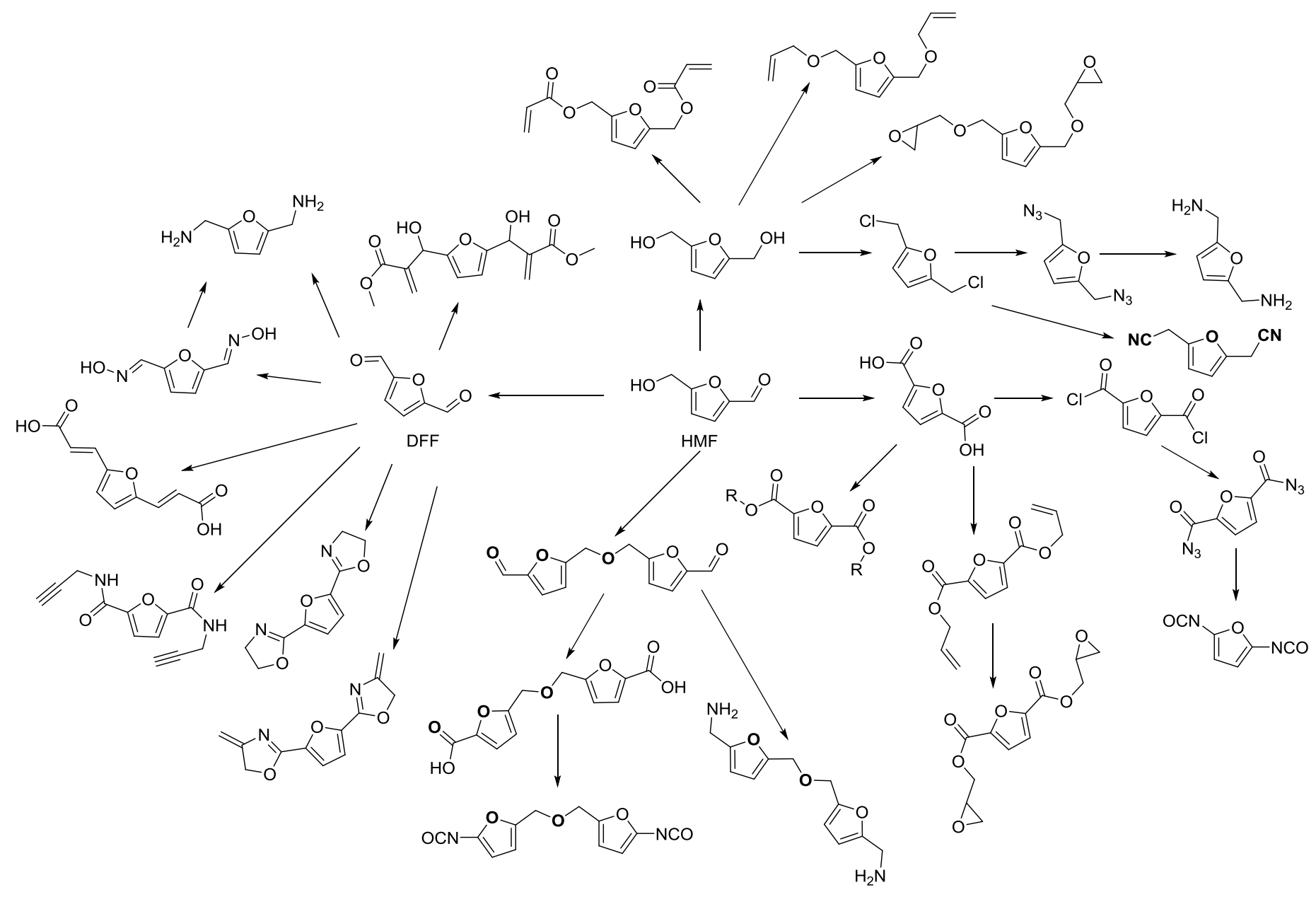

Scheme 3: wide range of monomers containing furan ring prepared from $5-\mathrm{HMF}^{48}$

Scheme 3 highlights the preparation of bio-based monomers, bearing a rigid moiety, as the obtained 2,5-furan dicarboxylic acid (FDCA) and 2,5furan dimethanol (FDM) which are relevant building blocks for a wide range of polymers such as polyesters ${ }^{57-61}$ and polyamides. ${ }^{62-}$ ${ }^{66}$ In addition, a more recent and comprehensive review on the microwave-assisted production of HMF from sugar, cellulose and polysaccharide feed has been discussed by Delbecq and Len. ${ }^{67}$ This review is divided into three main categories: (i) the use of various homogeneous catalysts such as mineral or organic acids, metal salts, or ionic liquids; (ii) feedstock dehydration making use of various solid acid catalysts; and (iii) non-catalytic route.

Other strategies, starting from chloromethyl furfural (CMF), have been proposed and Mascal $^{68}$ developed many original routes of synthesis.

In addition, taking into account the large amounts of raw products (cellulose, sugars, etc) and the wide applications of furan synthons (from energy to polymers), it is not surprising to note how 
the patents and publications are regularly increasing. In that area of polymer chemistry, it might be considered that one of the most important topics deals with polyesters and oxidation of HFM into 2,5-furan dicarboxylic acid, as well-mentioned in a recent review. ${ }^{69}$

To complete on polyesters and substitution of PET by biosourced alternatives, recent studies from furanoic derivatives into $\operatorname{aromatics}^{70}$ (e.g., dimethyl furane into paraxylene) ${ }^{71}$ can be mentioned, as well as those involving Diels Alder strategies. ${ }^{8}$

However, this review is devoted to the synthesis of epoxy compounds starting from furan derivatives.

Actually, two other criteria must be taken into account for the substitution of DGEBA: the quantity that can be produced and the price of the biobased substitute. ${ }^{72-76}$ Obviously, the mechanical performances of the resulting products resulting from such an alternative must be at least similar as those obtained from DGEBA. In addition, the products must be non-toxic.

All these requirements need to propose aromatic or pseudo-aromatic compounds, such as lignin or sugar derivatives as the most suitable substitutes.

First, vanillin, ${ }^{77}$ eugenol ${ }^{78}$ and cardanol $^{79}$ derivatives have been suggested while this present article reviews the furan products reported in the literature. Scheme 1 displays the process to get various furan derivatives from cellulose or hemicellulose. While furfural sounds straightforward from hemicellulose, hydroxymethyl furfural can be obtained from cellulose with levulinic acid as a side-product. ${ }^{80}$

The goal of this present review aims at supplying quasi-exhaustive synthetic pathways of epoxy precursors containing furan moieties and describing the resulting resins. However, molecules suited to lead to epoxy derivatives have been supplied even if their applications are not reported. Nevertheless, many strategies have been devoted to obtain furan dicarboxylic acid that is able to replace phthalic derivatives in polyethylene terephthalate (PET), ${ }^{81-83}$ which is a huge industrial challenge. Actually, other modifications of HMF moieties have been achieved to prepare acrylate, cyanate, urethane, etc... 


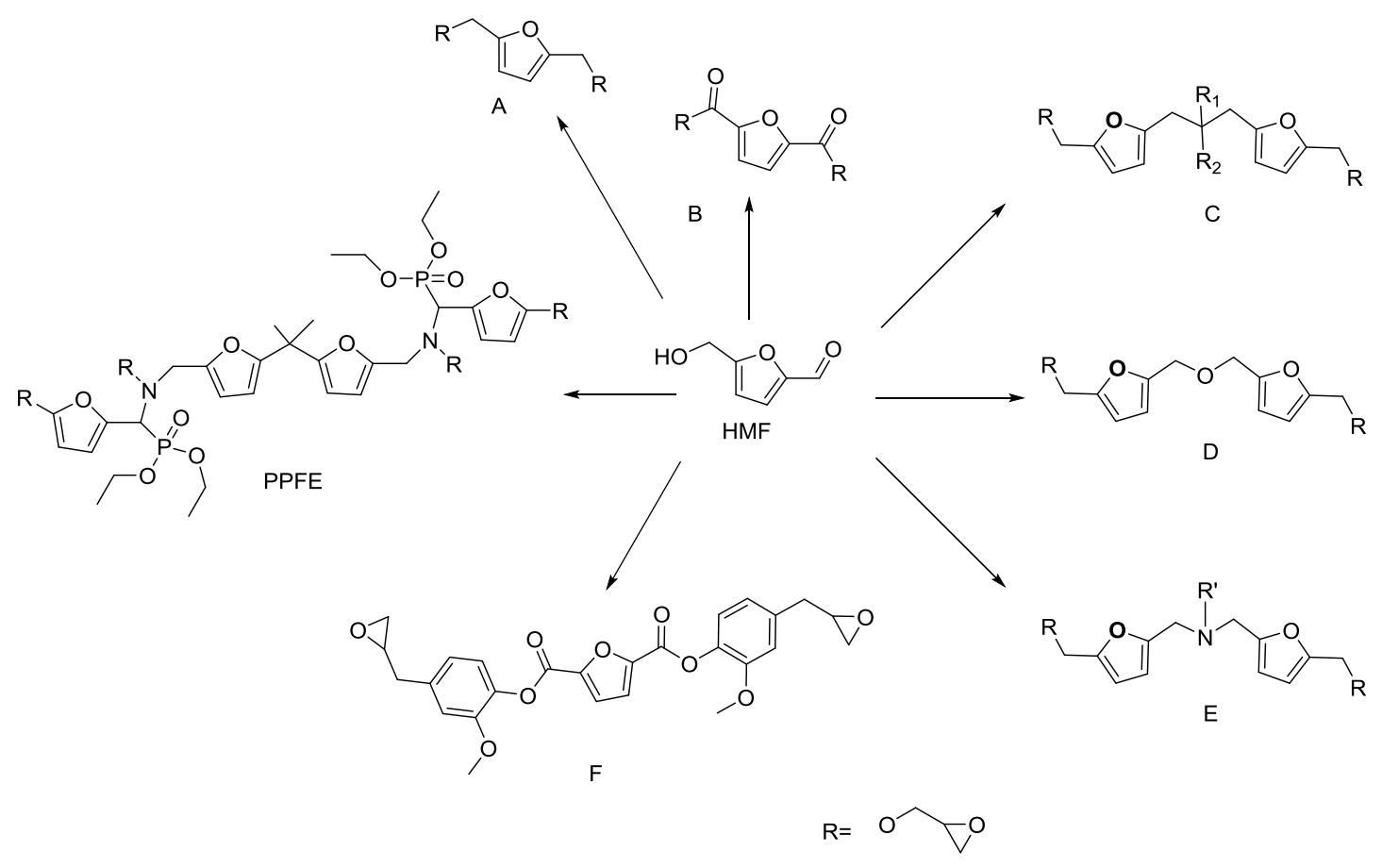

Scheme 4: Various telechelic bis(glycidyl) furans obtained from 5-HMF

\section{MAIN FAMILIES OF FURAN-CONTAINING DIEPOXY DERIVATIVES}

This review is composed of seven main parts: the first one deals with the synthesis of derivatives containing one furan nucleus only; the second one on bisfuran bearing a spacer between the furan ring and the function; while the third one supplied strategies affording polycyclic monomer, then a conclusion and perspectives are supplied.

Scheme 4 displays overall pathways of the seven functional furan-containing epoxides, prepared from HMF.

\section{2,5-Bis [(2-oxiranylmethoxy)methyl] furan (스).}

In 2013, Cho et $a l .{ }^{46}$ pioneered the preparation of telechelic diepoxy, 2,5-bis[(2oxiranylmethoxy)methyl] furan (BOF) starting from 2,5-bis(hydroxymethyl) furan, as depicted in Scheme 5.

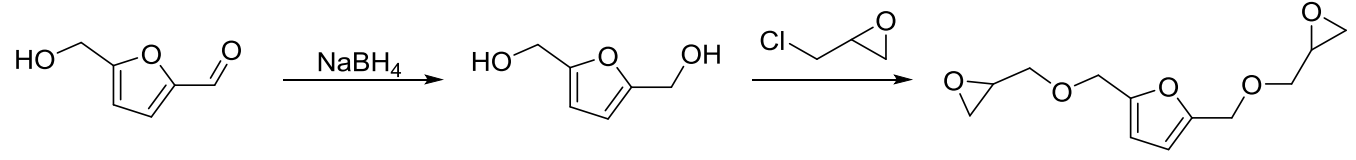

Scheme 5:Preparation of 2,5-bis [(2-oxiranylmethoxy)methyl] furan (BOF) from 5-HMF ${ }^{46}$

The resulting product was purified by column chromatography leading to a yellow liquid obtained in $60 \%$ yield. Surprisingly, the authors did not perform any classic epoxy networks but they studied its photoinitiated cationic homopolymerization. The targeted application of the resulting resins was adhesives. 
In 2014, Palmese's team ${ }^{84}$ synthesized and studied the properties of the same epoxy monomer (A) crosslinked by the diamines (4,4'-methylenebiscyclohexanamine (PACM) and diethyl toluene diamine (EPI)), as depicted in Figure 1.
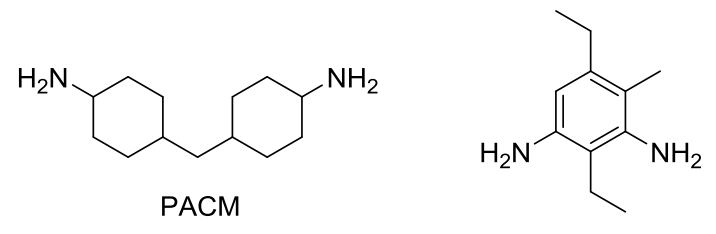

EDICURE W (EPI)

Figure 1: diamines used for crosslinking epoxy resins by Palmese team ${ }^{84}$

These authors reported an interesting comparison of the obtained products with that achieved from the aromatic homologue diepoxy (1,4-bis[(2-oxiranylmethoxy)methyl]-benzene, BOB) and the furan counterpart (BOF), Figure 2.
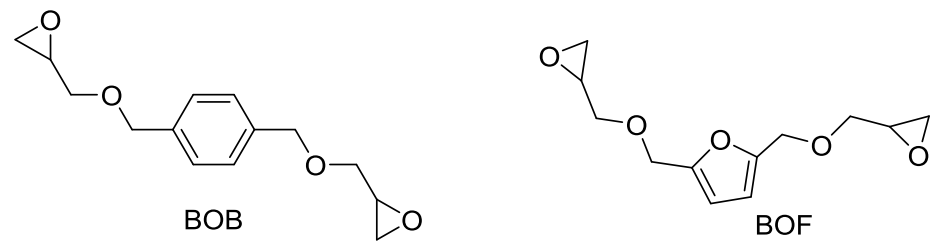

Figure 2: Aromatic (1,4-bis[(2-oxiranylmethoxy)methyl]-benzene, BOB) and furanoic homologue (2,5-bis[(2-oxiranylmethoxy) furan, BOF ) diepoxy monomers

Another diepoxy compound, named hydroquinone diepoxy (HQ), was also added for such a comparison in order to evaluate the effect of the methylene group between the aromatic (or pseudo aromatic) group and the ether function, starting from hydroquinone derivative (Figure 3).

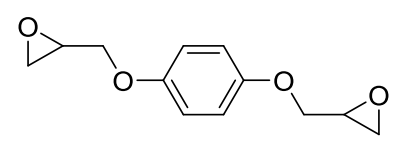

Figure 3: Hydroquinone derivative of $\mathrm{BOB}(\mathrm{HQ})$

Table 1 lists the Tg values (obtained from DMA) of the different resins, compared to those achieved from DGEBA. 
Table 1: Glass transition temperature $(\mathrm{Tg})$ of epoxy resins produced from $\mathrm{BOF}, \mathrm{BOB}, \mathrm{HQ}$ and DGEBA with various telechelic diamines (Figure 1) ${ }^{84}$

\begin{tabular}{|c|c|c|c|c|c|c|c|}
\hline & PACM & PACM & EPI & $\begin{array}{l}\text { EPI } \\
\mathrm{BOR}\end{array}$ & EPI & PACM & EP \\
\hline & $\mathrm{BOF}$ & $\mathrm{BOB}$ & $\mathrm{BOF}$ & $\mathrm{BOB}$ & $\mathrm{HQ}$ & DGEBA & DUEBA \\
\hline $\operatorname{Tg}\left({ }^{\circ} \mathrm{C}\right)$ & 71 & $\begin{array}{c}55 \\
100^{*}\end{array}$ & 88 & $\begin{array}{c}80 \\
132 *\end{array}$ & 193 & 167 & 185 \\
\hline
\end{tabular}

Several comments can be raised from these results:

i) the furan derivatives favor slightly higher $\mathrm{Tg}$ values, attributed to the hydrogen bonding brought by the furan moieties;

ii) All these $\mathrm{Tg}$ values are much lower (of ca. $100{ }^{\circ} \mathrm{C}$ ) than those of materials prepared from DGEBA due to the presence of the methylene spacer between the (pseudo)aromatic group and the epoxide moiety.

Actually, this methylene group induces some mobility that contributes to the decrease of the $\mathrm{Tg}$ values. These results are confirmed by the high Tg of the network produced from HQ that does not contain any $\mathrm{CH}_{2}$ group.

A similar behavior was also observed in the case of diepoxy-base vanillin (Figure 4). ${ }^{77}$

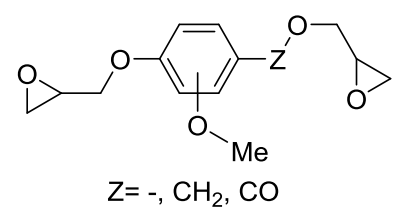

Figure 4: Telechelic diepoxy aromatic compound-based vanillin ${ }^{77}$

Palmese et al. ${ }^{84}$ also reacted these furan diepoxides by mixing BOF with DGEBA and studied the properties of the resulting networks. They noted that the Tg values followed the FoxFlory's law. These authors hence supplied a basic contribution for the understanding of the effect of the substitution of aromatic to furan series in reactants. Indeed, the furan derivatives always bear a linker $\left(\mathrm{CH}_{2}\right.$ or $\left.\mathrm{C}(=\mathrm{O})\right)$.

Similarly, the same team ${ }^{85}$ reported the synthesis of epoxy resins starting from both furan reactants containing diepoxy and diamine functions (Figure 5). The diamine was prepared via the condensation of 2-furfurylamine with the corresponding aldehyde or ketone, in acidic medium. The experimental protocols were simple, and the monomers were obtained in high yields without the need to especially protect the amine function since the acid plays the role of both the catalyst and the protecting agent. ${ }^{86-88}$ 


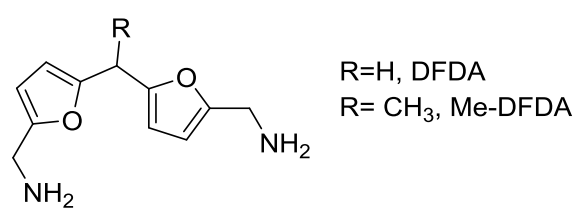

Figure 5: Diamine monomers prepared from furanoic starting materials ${ }^{85}$

The Tg values, listed in Table 2, were compared to those observed from DGEBA resins.

Table 2: Tg values of epoxy resins from BOF and DGEBA with furfurylamines as hardners ${ }^{85}$

\begin{tabular}{ccccccc}
\hline & BOF & BOF & BOF & DGEBA & DGEBA & DGEBA \\
& DFDA & Me-DFDA & PCAM & DFDA & Me-DFDA & PCAM \\
\hline $\operatorname{Tg}\left({ }^{\circ} \mathrm{C}\right)$ & 62 & 69 & 80 & 128 & 142 & 177 \\
\hline
\end{tabular}

As above, the $\mathrm{Tg}$ values are lower than those noted from DGEBA. However, from a totally furan resin, the char yield was ca. $40 \%$ while it was $6 \%$ from a network produced from other amines and DGEBA.

Various authors ${ }^{89-91}$ reported theoretical calculations on the influence of the moieties inserted in the structures of such compounds: the role of the spacer between both furan nuclei and those of oxygen and the methylene adjacent to the epoxy groups.

More recent investigations have been devoted to the development of BOF diepoxide. First, Guo et $a l .{ }^{91}$ cured the furan epoxy using two diamines, 3,3'-diaminodiphenyl sulfone (33 DDS) and 4,4'diaminodiphenyl sulfone (44 DDS), at high temperatures (Figure 6).<smiles>Nc1ccc(S(=O)(=O)c2ccc(N)cc2)cc1</smiles>

Figure 6: Telechelic diaminodiphenyl sulfone (33DDS and 44 DDS) ${ }^{91}$

A comparison on the thermal properties of the resulting epoxy resins with DGEBA in the same conditions is listed in Table 3.

Table 3: Glass transition temperature ( $\mathrm{Tg})$, decomposition temperature ( $5 \mathrm{wt} \%$ loss, $\mathrm{T}_{\text {dec }} \%$ ) and char of epoxy resins produced from BOF (or DGEBA) and DDS derivatives) ${ }^{85}$

\begin{tabular}{cccc}
\hline & $\operatorname{Tg}\left({ }^{\circ} \mathrm{C}\right)$ & $\mathrm{T}_{\mathrm{dec}} 5 \%\left({ }^{\circ} \mathrm{C}\right)$ & $\operatorname{char}(\%)$ \\
\hline BOF - 33 DDS & 102 & 380 & 44 \\
BOF - 44 DDS & 114 & 460 & 42 \\
DGEBA - 33 DDS & 184 & 418 & 20 \\
DGEBA - 44 DDS & 238 & 416 & 14 \\
\hline
\end{tabular}


(BOF, 33DDS and 44DDS stand for 2,5-bis[(2-oxiranylmethoxy)methyl]

furan, 3,3-diaminodiphenyl sulfone and 4,4-diaminodiphenyl sulfone,

respectively). Except the thermal stabilities of the resulting resins, the tendency is similar as that noted above.

Recently, Marotta et al. $^{92}$ studied the copolymerization of BOF with methyl-5norbornene-2,3-dicarboxylic anhydride (MNA) (Figure 7) at $130{ }^{\circ} \mathrm{C}$ and $180{ }^{\circ} \mathrm{C}$ in the presence of imidazole or dimethylbenzylamine, respectively (Table 4).<smiles>CC1CC2CCC1C1C(=O)OC(=O)C21</smiles>

Figure 7: structure of methyl-5-norbornene-2,3-dicarboxylic anhydride (MNA)

Table 4: Glass transition temperature ( $\mathrm{Tg}$ ) and decomposition temperature 5 wt\% loss ( $\mathrm{Tdec} 5 \%$ ), under nitrogen, of epoxy resins produced from BOF (or DGEBA) and MNA derivatives. ${ }^{92}$

\begin{tabular}{ccc}
\hline & $\operatorname{Tg}\left({ }^{\circ} \mathrm{C}\right)$ & $\mathrm{T}_{\operatorname{dec} 5 \%}\left({ }^{\circ} \mathrm{C}\right)$ \\
\hline BOF:MNA $(1: 1)$ & 50 & 256 \\
DGEBA:MNA $(1: 1)$ & 152 & 271 \\
\hline
\end{tabular}

The authors also used these formulations (BOF/MNA) incorporating $\mathrm{TiO}_{2}$ nanoparticles as fillers to elaborate original nanocomposite coatings. ${ }^{93}$

Furthermore, in an interesting article, Shen et al. ${ }^{94}$ studied the modification of BOF with maleimide via a Diels Alder reaction in order to introduce a flexible pendant chain by the maleimide functions with the objective to supply a method for toughening the biobased epoxy resin. These authors inserted various modified BOF (such as MBOF) amounts and showed that the $\mathrm{Tg}$ values decreased when increasing MBOF contents were used: $60{ }^{\circ} \mathrm{C}$ for $0 \% \mathrm{MBOF}$ to 40 ${ }^{\circ} \mathrm{C}$ when $\mathrm{MBOF}=100 \%$. However, $25 \%$ of maleimide remained present after curing although the retro Diels Alder reaction occurred. An optimum of $50 \%$ of MBOF led to better mechanical properties (e.g., impact resistance). Furthermore, the presence of free maleimide and MBOF enabled both a toughening effect of DA-BOF and a plasticizing effect.

\section{II - Diglycidyl ester of 2,5-furandicarboxylic acid (B)}

The first synthesis of diglycidyl ester of 2,5-furandicarboxylic acid (B) was reported by Liu et al. $^{89}$ from 2,5-furandicarboxylic acid (FDCA) in 2015, according to Scheme 6. 


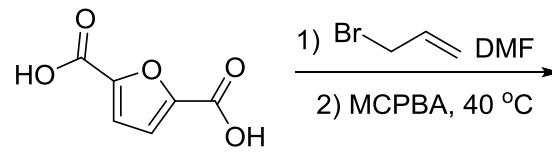

FDCA

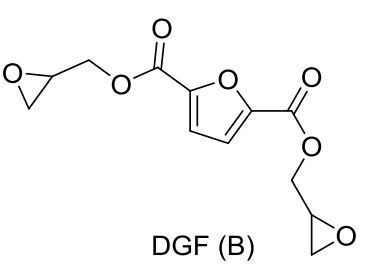

DGF (B)

Scheme 6: Two step-synthesis of telechelic diglycidylester of 2,5-furandicarboxylic acid DGF from FDCA ${ }^{89}$

Actually, FDCA is one of the twelve building blocks that is regarded as a platform for the synthesis of high-value biobased chemicals or materials. ${ }^{95}$ Indeed, a recent review ${ }^{69}$ reports some advances in catalytic oxidation of HMF towards FDCA as well as other HMF oxidation intermediates: 2,5-diformylfuran, 5-hydroxymethyl-2-furancarboxylic acid, 5-formyl-2furancarboxylic acid. More recently, the same group ${ }^{96}$ also obtained FDCA from HMF under microwave-assisted heating using hydrogen peroxide and various ruthenium catalysts.

Liu's group ${ }^{89}$ compared the reactivity of telechelic diepoxy DGF to the corresponding diglycidyl terephthalate (DGT) and the resulting epoxy resins were produced after curing via two kinds of crosslinkers: an anhydride (methyl hexahydrophthalic anhydride MHHPA) and a telechelic diamine polyether, poly(propylene glycol)-bis(2-aminopropylether), Jeffamine®D230 (Figure 8).<smiles>CC12CCCCC1C(=O)OC2=O</smiles>

MHHPA<smiles>C=C(N)COC(C)C(C)N</smiles>

D 230<smiles>O=C(OCC1CO1)c1ccc(C(=O)OCC2CO2)cc1</smiles>

DGT

Figure 8: Hardeners used with FDGA diepoxies: methyl hexahydrophthalic anhydride (MHHPA), poly(propylene glycol)-bis(2aminopropylether) (D230) and diglycidyl terephthalate (DGT)

The curing behavior was highlighted by DSC, occurring at $120^{\circ} \mathrm{C}-140{ }^{\circ} \mathrm{C}$ in presence of the anhydride and at $90-110^{\circ} \mathrm{C}$ with the bisamine. ${ }^{89}$ The $\mathrm{Tg}$ values of the epoxy resins are listed in Table 5.

Table 5: Tg values of resins prepared from glycidyl reactants (where D230 stands for poly(propylene glycol)-bis(2aminopropylether (Jeffamine ${ }^{\oplus D 230}{ }^{89}$ )

\begin{tabular}{lcccccc}
\hline & DGF & DGF & DGT & DGT & DGEBA & DGEBA \\
& MHHPA & D230 & MHHPA & D230 & MHHPA & D230 \\
\hline $\mathrm{Tg}\left({ }^{\circ} \mathrm{C}\right)$ & 152 & 129 & 101 & 92 & 125 & 97 \\
\hline
\end{tabular}

Table 5 highlights several features: i) the Tg value of the resulting resins obtained from DGF is higher than those prepared from DGT and DGEBA, and ii) the Tg value of the material produced from DGT was slightly lower than that achieved from DGEBA and iii). The 
introduction of carbonyl group in the structure enabled to increase the rigidity of the resin and, consequently, the $\mathrm{Tg}$, as this was already observed in the vanillin series. ${ }^{77}$

In addition, the thermal stabilities are almost similar in the presence of the same crosslinkers.

Liu's group ${ }^{97}$ revisited that work by comparing the products obtained from telechelic furan dicarboxylic and aromatic biscarboxylic epoxy derivatization, starting from isophthalic isomer and 4,4'-diaminodiphenylmethane (DDM) aromatic diamine (figure 9). As above, the Tg value of the resulting network from the furan product was higher than that involving the aromatic one $\left(156^{\circ} \mathrm{C}\right.$ versus $124^{\circ} \mathrm{C}$ ), as well as other physical characteristics (surface energies, and mechanical properties as tensile strength higher than corresponding aromatic network). These authors explained such features by the formation of hydrogen bonding arising from the oxygen atom in the furan core.

Guo's team ${ }^{98}$ reported the quasi same synthesis but these authors substituted DDM by 33 and 44 DDS (Figure 9) to yield epoxy resins, the thermal and mechanical properties of which are listed in Table 6.
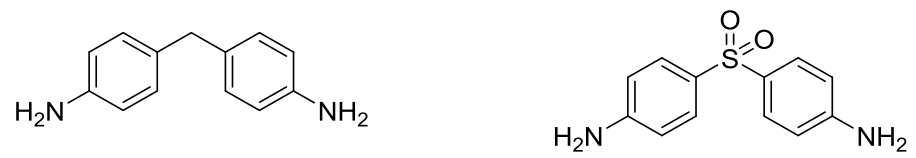

Figure 9: Telechelic diamine hardeners, 4,4'-diaminodiphenylmethane (DDM) and 4,4'-diaminodiphenylsulfone (44 DDS) used in the curing reaction ${ }^{98}$

Table 6: Thermomechanical and mechanical properties of resins produced from DGF, DGEBA, 33 DDS and 44 DDS ${ }^{98}$

\begin{tabular}{ccccccccc}
\hline Entry & Sample & $\begin{array}{c}\mathrm{Tg}^{\mathrm{a}} \\
\left({ }^{\circ} \mathrm{C}\right)\end{array}$ & $\begin{array}{c}\mathrm{E}^{\mathrm{b}} \\
(\mathrm{MPa})\end{array}$ & $\begin{array}{c}\mathrm{E}^{\mathrm{c}} \\
(\mathrm{MPa})\end{array}$ & $\begin{array}{c}\mathrm{V}_{\mathrm{e}} \\
\left(\mathrm{mol} / \mathrm{dm}^{3}\right)\end{array}$ & $\begin{array}{c}\text { Tensile } \\
\text { Strength } \\
(\mathrm{MPa})\end{array}$ & $\begin{array}{c}\text { Elongation at } \\
\text { break }(\%)\end{array}$ & $\begin{array}{c}\text { Shore } \\
\text { hardness } \\
(\mathrm{HD})\end{array}$ \\
\hline 1 & $\begin{array}{c}\text { DGF/ } \\
33 \mathrm{DDS}\end{array}$ & 180 & 3921 & 26 & 2.48 & 56 & 8.5 & 88.3 \\
2 & $\begin{array}{c}\text { DGF/ } \\
44 \mathrm{DDS}\end{array}$ & 216 & 2510 & 25 & 1.39 & 50.2 & 13.8 & 86.9 \\
3 & $\begin{array}{c}\text { DGEBA/ } \\
33 \mathrm{DDS}\end{array}$ & 178 & 1858 & 18 & 1.46 & 49.9 & 8.2 & 76.6 \\
4 & $\begin{array}{c}\text { DGEBA/ } \\
44 \mathrm{DDS}\end{array}$ & 237 & 1932 & 16 & 1.18 & 44.6 & 10.3 & 80.5 \\
\hline
\end{tabular}

${ }^{\mathrm{a}}$ From DMA ${ }^{\mathrm{b}}$ Values at $20{ }^{\circ} \mathrm{C}{ }^{\mathrm{c}}$ Values at $\mathrm{Tg}+30{ }^{\circ} \mathrm{C}$; E and Ve stand for storage modulus and crosslinking density, respectively

Although the $\mathrm{Tg}$ value of the material obtained from $\underline{B}$ is quite high, that from DGEBA achieved with the same hardener is even higher $\left(237^{\circ} \mathrm{C}\right)$. These results are different from those 
reported by Liu et al. ${ }^{97}$ who used an anhydride as the hardener and, surprisingly, with polyether diamine but no explanation has been given so far

In addition, Marotta et al..$^{99}$ investigated two methods to synthetize $\underline{\mathrm{B}}$ :

i) the first one involves FDCA with epichlorhydrine as the conventional pathway used for vanillic acid ${ }^{77}$ or gallic acid. ${ }^{100}$ The product was purified by column chromatography. ${ }^{1} \mathrm{H}$ NMR spectroscopy confirmed the structure but the ratio of integrals of the signals assigned to furan and epoxide functions led to an average degree of polymerization of 0.17 highlighting the formation of oligomers (Figure 10).

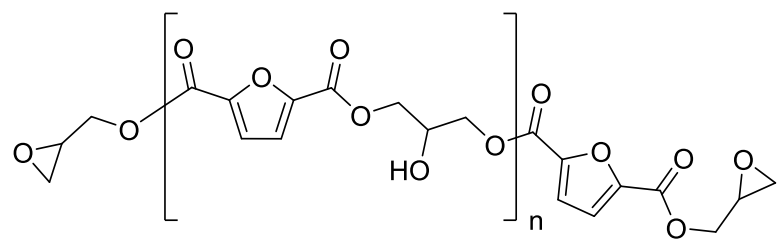

Figure 10: Telechelic Diepoxy terminated oligo(2,5-furanoic glycerol) ${ }^{99}$

ii) The second method dealt with the transesterification of methyl ester of FDA with an excess of glycidol at low temperature in the presence of $\mathrm{KOCN}$ as the catalyst. As above, the purification of the product was achieved by column chromatography. In that case, the epoxy equivalent weight (EEW) value was low (135 compared to 152) with an average degree of polymerization of 0.011 while its melting point was $88^{\circ} \mathrm{C}$ (DSC). Unfortunately, the authors did not report any yield of the product obtained from both pathways.

In 2018, Johansson et al. ${ }^{101}$ studied the copolymerization of $\underline{\mathrm{B}}$ with epoxidized fatty methyl esters, either thermally or under UV-induced cationic initiation (onium salt). B was obtained from diallyl furan-2,5-dicarboxylate (DAFDC) and meta-chloroperbenzoic acid (mCPBA), epoxidation (Scheme 7). The decreasing order of the reactivity, monitored by DSC, was as follows, for various oil : furan epoxy mixtures ranging from 5:1 to 1:5:

oil monoepoxy > oil diepoxy > oil triepoxy >> furan epoxy (B).

The Tg values varied between $-23{ }^{\circ} \mathrm{C}$ to $65^{\circ} \mathrm{C}$, considering the increasing furan content. When DGEBA replaced FDCA (B) with epoxidized oil, the Tg values of the obtained epoxy resin were almost the same. Finally, the storage modulus varied from 1.0 to $2.7 \mathrm{GPa}$, rather similar as that of PET.

As a matter of fact, one fashionable application from BOF deals with the synthesis of non-isocyanate polyurethanes (NIPUs). ${ }^{102}$ The carbonatation of BOF led to telechelic 
bis(cyclocarbonate) which, added onto telechelic poly(methylene) diamines, yielded original NIPUs (Scheme 7).<smiles>O=C(O)c1ccc(C(=O)O)o1</smiles>
FDCA<smiles>C=CCOC(=O)c1ccc(C(=O)OCC)o1</smiles>

diallyl furan-2,5-dicarboxylate<smiles>O=C(OCC1CO1)c1ccc(C(=O)OCC2CO2)o1</smiles>

Diglycidyl ester of FDCA (BOF)

$\mathrm{CO}_{2}$<smiles>CCC(C)(C)NNC(=O)OCC(O)COC(=O)c1ccc(C(=O)OCC(CO)OC(=O)C(C)(C)C(C)(C)N)o1</smiles><smiles>O=C1OCC(COC(=O)c2ccc(C(=O)OCC3COC(=O)O3)o2)O1</smiles>

Scheme 7: Synthesis of non-isocyanate polyurethanes (NIPUs) from the dimethylol furan (BOF). ${ }^{102}$

According to the nature of the telechelic diamine, the obtained NIPUs were amorphous with a broad range of Tgs varying from $63{ }^{\circ} \mathrm{C}$ to $113{ }^{\circ} \mathrm{C}$. As expected, the rigid chemical structure of cycloaliphatic diamine led to higher Tg of the resulting NIPUs than that observed when softer linear aliphatic diamines were used.

To conclude in this section, it can be noted that such a B derivative is the logically most used but the presence of ester moieties enables to increases the $\mathrm{Tg}$ of the resulting epoxy resins but they also induced weak points toward hydrolysis.

\section{III) Bis(furan) Bearing Alkyl Spacers (C)}

In 2013, Cho et al. ${ }^{46}$ described a three-step synthesis of diepoxy bis(furan) in which both furan groups are separated by an isopropyl group (Scheme 8).<smiles>COC(=O)c1ccco1</smiles>

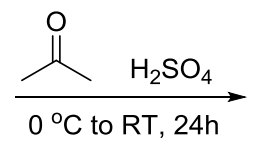<smiles>COC(=O)c1ccc(C(C)(C)c2ccc(C(=O)OC)o2)o1</smiles>

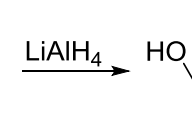<smiles>Cc1ccc(C(C)(C)c2ccc(CO)o2)o1</smiles>

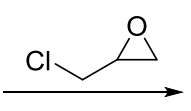<smiles>CC(C)(c1ccc(COCC2CO2)o1)c1ccc(COCC2CO2)o1</smiles>

(C)

Scheme 8: synthesis of telechelic diepoxy bis(Furan) starting from methyl furanoic methyl ester ${ }^{46}$ 
The overall yield was low (40\%) and these steps require toxic or hazardous reactants. Thus, Sucheck's group ${ }^{103}$ suggested another pathway (Scheme ) and could reach $47 \%$ overall yield. To the best of our knowledge, such a telechelic bisepoxy bis(furan) has never been involved in the synthesis of epoxy resins, though Cho et $a l^{46}$ used them under cationic photopolymerizations. Surprisingly and based on the structure of the precursor diol, the authors deduced that this compound cannot display any estrogenic activity in contrast to that of bisphenol A (BPA). ${ }^{103}$ While with aromatic synthons, this is the most used method, and in the case of furans, only one has been reported. ${ }^{46}$
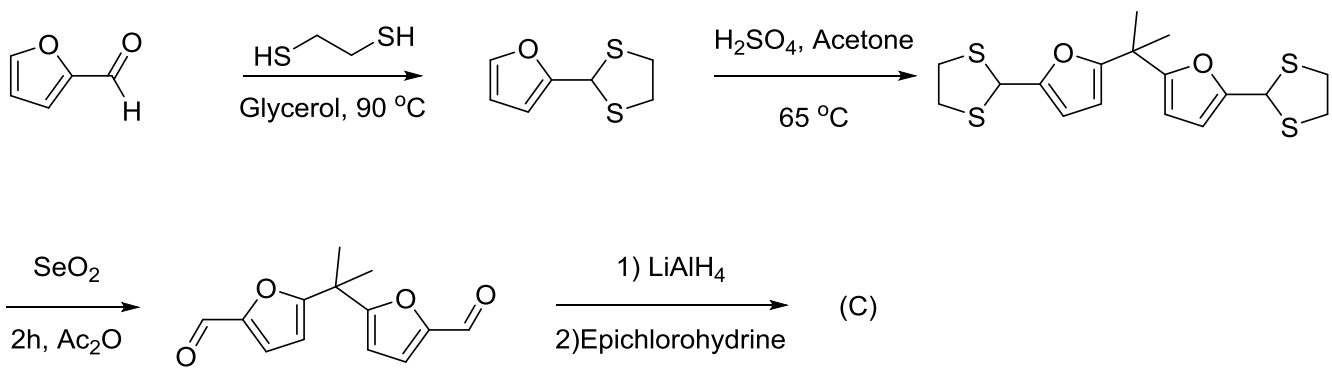<smiles>CC(C)(c1ccc(C=O)o1)c1ccc(C=O)o1</smiles>

$\underset{\text { 2)Epichlorohydrine }}{\stackrel{\text { 1) } \mathrm{LiAlH}_{4}}{\longrightarrow}}$

Scheme 9: synthesis of telechelic diepoxy bis(furan) (C) from furfural in a 5 step-reaction ${ }^{103}$

To conclude on this short section, because furfural is a quite abundant, cheap, and stable compound in contrast to 5-HMF, this strategy to prepare furan $\mathrm{C}$ is remarkable and will probably lead to many innovations.

IV) Bis(furan) with an Ether Spacer between furan rings (D)

Meng et al. ${ }^{104}$ have recently proposed the preparation of a new telechelic bis(epoxy) derivatives directly obtained from HMF via a simple self-etherification in acidic conditions (Scheme 10). This etherification reaction was inspired from Casanova et al. ${ }^{105}$ and Bell's team ${ }^{106}$ for searching new bio-diesel alternatives.
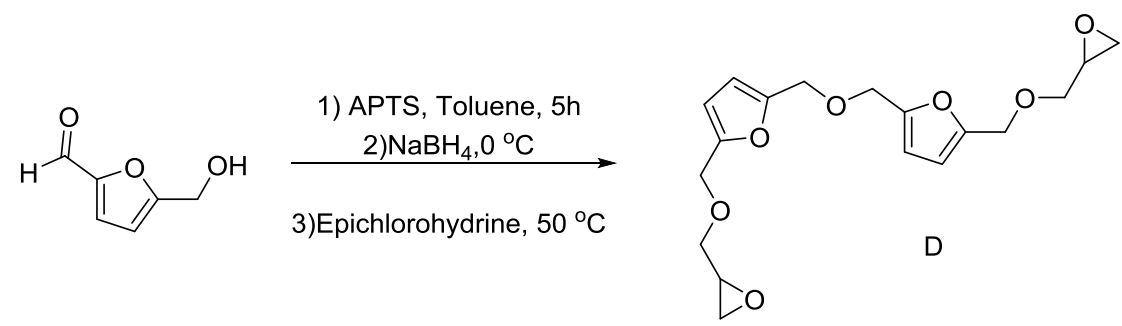

Scheme 10: new telechelic bis(epoxy) from hydroxymethyl furfural (HMF) via self-etherification ${ }^{104}$

Another method to produce a (bis)aldehyde intermediate to avoid the levulinic acid side product was reported by Chundury and Szmant, ${ }^{107}$ starting from HMF and 5-chloromethyl 
furfural (Scheme 11), although these authors have not further developed the synthesis of the resin.

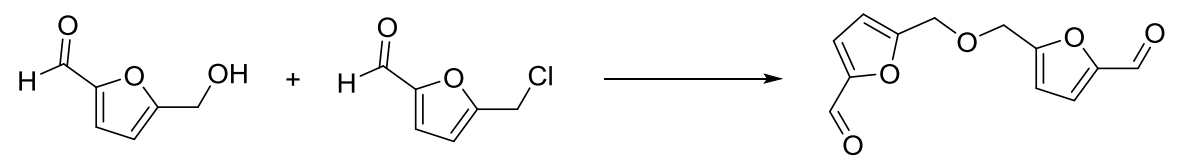

Scheme 11: Prepation of bis(aldehyde) from 5-HMF and 5-chloro HMF ${ }^{107}$

Actually, such a novel diepoxy $(\underline{D})$ has been reacting onto Jeffamine® hardener:

$\mathrm{H}_{2} \mathrm{~N}-\left(\mathrm{CH}_{2} \mathrm{CH}_{2} \mathrm{O}\right)_{\mathrm{x}}-\mathrm{CH}_{2} \mathrm{CH}_{2} \mathrm{NH}_{2}$, with $\mathrm{x}=1(\mathrm{~F} 1) ; \mathrm{x}=2(\mathrm{~F} 2) ; \mathrm{x}=3(\mathrm{~F} 3)$

The thermal properties ( $\mathrm{Tg}$ ) of the resulting materials were compared to those obtained from $\mathrm{BOF}(\underline{\mathrm{A}})$ and the results are summarized in Table $7 .{ }^{104}$

Table 7: Tg values of epoxy resins prepared from (D)F and (A)Fi (where Fi stands for a telechelic diamine) ${ }^{107}$

\begin{tabular}{ccccccc}
\hline Resin & $(\mathrm{D}) \mathrm{F}_{1}$ & $(\mathrm{D}) \mathrm{F}_{2}$ & $(\mathrm{D}) \mathrm{F}_{3}$ & $(\mathrm{~A}) \mathrm{F}_{1}$ & $(\mathrm{~A}) \mathrm{F}_{2}$ & $(\mathrm{~A}) \mathrm{F}_{3}$ \\
\hline $\mathrm{Tg}\left({ }^{\circ} \mathrm{C}\right)$ & 25 & 21 & 7 & 14 & 13 & 8 \\
\hline
\end{tabular}

Obviously, such determined $\mathrm{Tg}$ values were low but not as low as those observed in epoxy resins achieved from BOF. This is not expected taking into account the presence of a soft spacer (as $-\mathrm{CH}_{2}-\mathrm{O}-\mathrm{CH}_{2}$ ) between both furan groups.

The thermal stabilities are slightly lower (of 20 to $30{ }^{\circ} \mathrm{C}$ ) compared to that of network from BOF. Interestingly, all the resulting materials displayed satisfactory fire resistance properties. $^{104}$

In conclusion of this sub-section, this etherification strategy in the presence of a strong acid is simple, cheap and direct, and would deserve to be further continued in the future.

\section{V) Bis(furan)s containing an amine spacer (E)}

Zhang et al. ${ }^{108}$ successfully prepared an HMF-based diol monomer with an amine spacer using reductive amination in the presence of a ruthenium catalyst (Scheme 12).

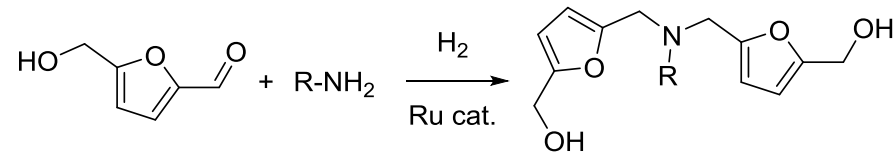

Scheme 12: Condensation of HMF with a primary amine to lead to a telechelic diol bis(furan) (where R stands for a benzyl or aliphatic substituent) ${ }^{108}$ 
First, the nature of the ligand in the catalyst is essential and homogeneous ruthenium (II) having sterically hindered ligand was preferred. Actually, the best yields were achieved when aliphatic in alpha-C position and benzyl amine were used, reaching $90 \%$ when the reaction was carried out under 20 bar-hydrogen at $110{ }^{\circ} \mathrm{C}$ for 12 hours. Indeed, no reaction occurred when an aromatic or an aliphatic primary amine were used. The authors proposed a mechanism that led to an imine formation that can further be hydrogenated to its corresponding secondary amine. Then, this latter reacted onto the other HMF, thus yielding the bis(furan) diol. However, the authors did not further use these derivatives in specific reactions.

To conclude, the presence of that secondary amine may help in the catalysis of the reaction between the epoxy reactant and the hardener.

\section{VI) Furan Dicarboxylic acid Modified Eugenol (F)}

In 2017, Gu's team ${ }^{109}$ synthesized an original and totally biobased telechelic epoxy in three steps from 1,4-bis(dicarboxylic acid) furan, involving eugenol in the second step (Scheme 13) :

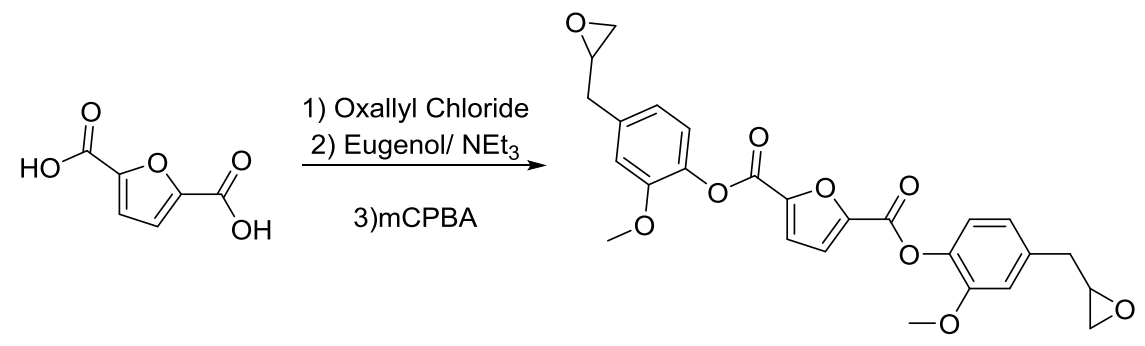

Scheme 13: the three step-synthesis of an aromatic telechelic glycidyl Furan from FDCA. ${ }^{109}$

This diepoxy can be cured by MHHPA and the DSC thermograms revealed a reaction starting from $142{ }^{\circ} \mathrm{C}\left(140{ }^{\circ} \mathrm{C}\right.$ in the case of DGEBA $)$. They led to materials, the $\mathrm{Tg}$ values of which were $153{ }^{\circ} \mathrm{C}\left(144{ }^{\circ} \mathrm{C}\right.$ from DGEBA $)$.

When $\underline{\mathrm{F}}$ was involved in that curing, the thermal stabilities of the produced resins were $50{ }^{\circ} \mathrm{C}$ lower than those obtained from DGEBA. On the contrary, the char yield was much higher as well as the fire resistance, compared to those of the product obtained from DGEBA.

In 2020, Gu et al. ${ }^{110}$ claimed (in a patent) the process for the preparation of the molecule. Surprisingly, this patent does not refer the previous article ${ }^{109}$ published three years before by the same authors.

In a similar manner, Chen et al. ${ }^{15}$ studied the curing process of compound $\underline{F}$ in the presence of 4-dimethylaminopyridine (DMAP). In addition, the authors also used another diacid chloride, $\mathrm{ClC}(\mathrm{O})\left(\mathrm{CH}_{2}\right)_{\mathrm{n}}-\mathrm{C}(\mathrm{O}) \mathrm{Cl}$ with $\mathrm{n}=1,2,3$, without any furan group. The originality of this 
survey arises from the curing mechanism. Actually, using model compounds, the authors showed that the activated ester reacted onto the epoxide ring in the presence of DMAP, ${ }^{111}$ as in the reaction model displayed in Scheme 14 .

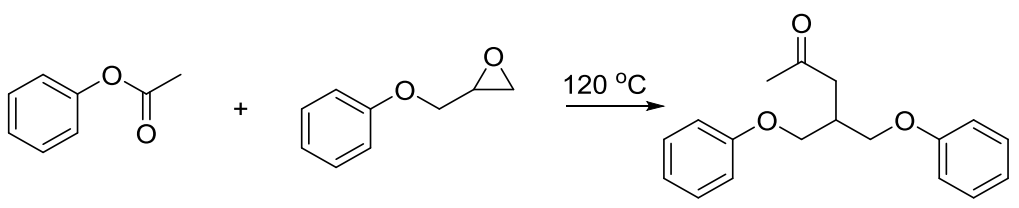

Scheme 14: Condensation between an aromatic acetate derivative and an epoxide compound ${ }^{111}$

By DSC, the authors assigned an exothermal peak (at ca. $170{ }^{\circ} \mathrm{C}$ ) in the reaction from compound $\underline{\mathrm{F}}$.

However, that strategy requires a diacyl chloride and thus, it potentially induces some issues for an industrial scale up.

VII) Telechelic bisepoxy(furan) containing a bisfurfurylamine and phosphonate functional group

$\underline{(\mathrm{G})}$

Park et al. ${ }^{112}$ prepared a furan-based epoxy resin containing phosphorus group (PPFE) by Kabachnic-Field reaction, ${ }^{13,114}$ using HMF, difurfuryl diamine (DFDA) and diethylphosphite (Scheme 15).

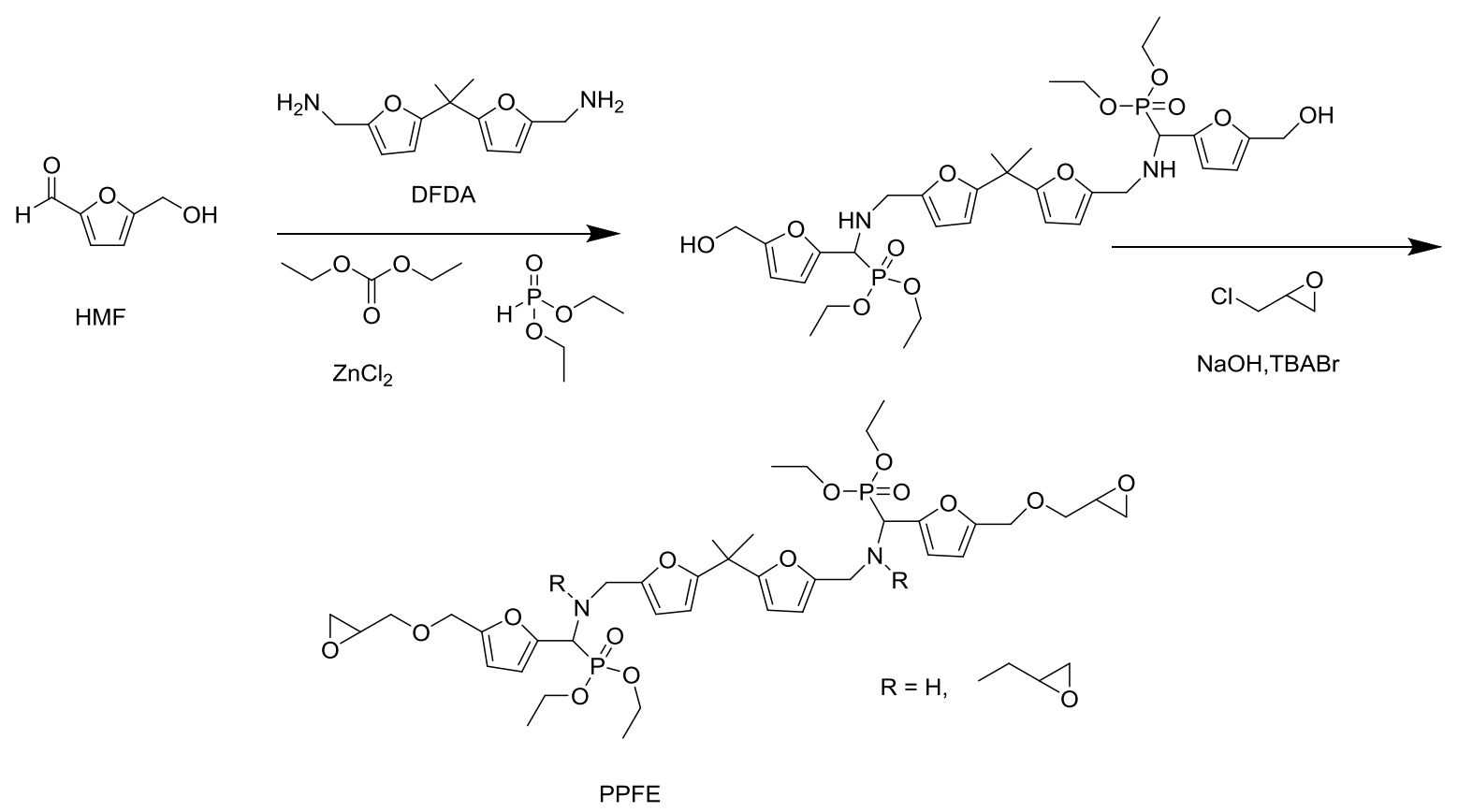

Scheme15: synthesis of a tetra(furan)containing diethyl phosphonate function (PPFE)

The thermosets were formulated from BOF, BOF/PPFE and in presence of DFDA as the curing agent. The thermal, mechanical, and flame retardancy properties of the resulting materials were compared to those achieved from DGEBA as the reference. Owing to the furan and phosphonate 
groups, those materials display enhanced properties compared to those of BOF-DFDA, as well as the flame-retardant behavior compared to the reference product.

\section{CONCLUSION AND PERSPECTIVES}

This review shows that all developed research favor opportunities to replace BPA-based epoxy resins by epoxy containing furan. It can be concluded that these latter led to materials having Tg values lower than those obtained from BPA because of the presence of the methylene group adjacent to furan ring induces softness, except if the reactant is FCDA, this latter possessing a $\mathrm{C}=\mathrm{O}$ function in $\alpha$-position. Similarly, thermal stabilities are generally lower, but flame retardancy and char yield are much higher compared to those of materials produced from BPA. Interestingly, the synthesis of amine hardener starting from furfural enabled the synthesis of totally biobased epoxy derivatives.

To complete all these surveys, it could be of interest to plan new approaches. First, oxidation reactions of HMF are much more studied (as well as more simple) and preparing a telechelic dicarboxylic furan acid had been the first motivation. On the contrary, the reduction of HMF by $\mathrm{NaBH}_{4}$, and in a further extend, the reduction of acid (or ester) by $\mathrm{LiAlH}_{4}$ represents innovative challenges. Second, using furfural, that is a more abundant raw material, and much easier to obtain, remains one of the hottest topics of research since it is involved in various topics as green solvents and energy (clean fuels). However, this is a monofunctional compound and it will be of interest to have bis or multifunctional derivatives. In addition, HMF leading to various polymers, undergoes some hydrolysis side reactions into levulinic acid that induces low yield and hence its purification must be optimized. Except the investigations from Cho et al. ${ }^{46}$ and Sucheck et al. ${ }^{103}$ and the diepoxydation of furfuryl amine, ${ }^{114}$ quite a few articles and patents have been published compared to the homologue series of products from aromatic reactants (e.g. addition of aldehydes and ketones onto aromatic rings of phenolic compounds).

The direct production of 5-(chloromethyl) furfural, proceeds in high yields directly from cellulose and cellulosic biomass, as reported by Mascal. ${ }^{68}$ Hence, further studies are expected in the coming decades and should attract the interest of many academic as well as industrial researchers.

Finally, regarding the future of biosourced resins, as mentioned above, furan and fatty oils are promising building blocks for epoxy resin preparation because of huge available feedstocks.

\section{References}

(1) Jin, F.-L.; Li, X.; Park, S.-J. Synthesis and Application of Epoxy Resins: A Review. J. Ind. Eng. Chem. 2015, 29, 111. https://doi.org/10.1016/j.jiec.2015.03.026. 

Ebenso, E. E. Epoxy Resins as Anticorrosive Polymeric Materials: A Review. React. Funct. Polym. 2020, 156, 104741. https://doi.org/10.1016/j.reactfunctpolym.2020.104741.

(3) Sprenger, S. Epoxy Resin Composites with Surface-Modified Silicon Dioxide Nanoparticles: A Review. J. Appl. Polym. Sci. 2013, 130 (3), 1421-1428. https://doi.org/10.1002/app.39208.

(4) Ho, T.-H.; Wang, C.-S. Modification of Epoxy Resins with Polysiloxane Thermoplastic Polyurethane for Electronic Encapsulation: 1. Polymer 1996, 37 (13), 2733-2742. https://doi.org/10.1016/00323861(96)87635-X.

(5) Guadagno, L.; Raimondo, M.; Vittoria, V.; Vertuccio, L.; Naddeo, C.; Russo, S.; Vivo, B. D.; Lamberti, P.; Spinelli, G.; Tucci, V. Development of Epoxy Mixtures for Application in Aeronautics and Aerospace. RSC Adv. 2014, 4 (30), 15474-15488. https://doi.org/10.1039/C3RA48031C.

(6) Ng, F.; Couture, G.; Philippe, C.; Boutevin, B.; Caillol, S. Bio-Based Aromatic Epoxy Monomers for Thermoset Materials. Molecules 2017, 22 (1), 149. https://doi.org/10.3390/molecules22010149.

(7) Products https://www.spolchemie.cz/en/homepage/Products/EnviPOXY\%C2\%AE/Cat (accessed Dec 15, 2020).

(8) Gandini, A.; Lacerda, T. M.; Carvalho, A. J. F.; Trovatti, E. Progress of Polymers from Renewable Resources: Furans, Vegetable Oils, and Polysaccharides. Chem. Rev. 2016, 116 (3), 1637-1669. https://doi.org/10.1021/acs.chemrev.5b00264.

(9) Dai, J.; Peng, Y.; Teng, N.; Liu, Y.; Liu, C.; Shen, X.; Mahmud, S.; Zhu, J.; Liu, X. High-Performing and FireResistant Biobased Epoxy Resin from Renewable Sources. ACS Sustain. Chem. Eng. 2018, 6 (6), 7589-7599. https://doi.org/10.1021/acssuschemeng.8b00439.

(10) Maffini, M. V.; Rubin, B. S.; Sonnenschein, C.; Soto, A. M. Endocrine Disruptors and Reproductive Health: The Case of Bisphenol-A. Mol. Cell. Endocrinol. 2006, 254-255, 179-186.

https://doi.org/10.1016/j.mce.2006.04.033.

(11) Lawrence, W. H.; Malik, M.; Turner, J. E.; Autian, J. Toxicity Profile of Epichlorohydrin. J. Pharm. Sci. 1972, 61 (11), 1712-1717. https://doi.org/10.1002/jps.2600611103.

(12) John, J. A.; Quast, J. F.; Murray, F. J.; Calhoun, L. G.; Staples, R. E. Inhalation Toxicity of Epichlorohydrin: Effects on Fertility in Rats and Rabbits. Toxicol. Appl. Pharmacol. 1983, 68 (3), 415-423. https://doi.org/10.1016/0041-008X(83)90286-7.

(13) Hutler Wolkowicz, I. R.; Aronzon, C. M.; Pérez Coll, C. S. Lethal and Sublethal Toxicity of the Industrial Chemical Epichlorohydrin on Rhinella Arenarum (Anura, Bufonidae) Embryos and Larvae. J. Hazard. Mater. 2013, 263, 784-791. https://doi.org/10.1016/j.jhazmat.2013.10.018.

(14) Gandini, A. "Epoxy Polymers Based on Renewable Resources" In Pascault, J.P.; Williams R.J.J., Eds; Epoxy Polymers: New materials and innovations; John Wiley \& Sons, Ltd, 2010; Chapter 4; pp 55-78. https://doi.org/10.1002/9783527628704.ch4.

(15) Chen, C.-H.; Tung, S.-H.; Jeng, R.-J.; M. Abu-Omar, M.; Lin, C.-H. A Facile Strategy to Achieve Fully Bio-Based Epoxy Thermosets from Eugenol. Green Chem. 2019, 21 (16), 4475-4488. https://doi.org/10.1039/C9GC01184F.

(16) Ma, Y.; Liu, H.; Wu, J.; Yuan, L.; Wang, Y.; Du, X.; Wang, R.; Marwa, P. W.; Petlulu, P.; Chen, X.; Zhang, H. The Adverse Health Effects of Bisphenol A and Related Toxicity Mechanisms. Environ. Res. 2019, 176, 108575. https://doi.org/10.1016/j.envres.2019.108575.

(17) Michałowicz, J. Bisphenol A - Sources, Toxicity and Biotransformation. Environ. Toxicol. Pharmacol. 2014, 37 (2), 738-758. https://doi.org/10.1016/j.etap.2014.02.003.

(18) Matthews, J. B.; Twomey, K.; Zacharewski, T. R. In Vitro and in Vivo Interactions of Bisphenol A and Its Metabolite, Bisphenol A Glucuronide, with Estrogen Receptors $\alpha$ and $\beta$. Chem. Res. Toxicol. 2001, 14 (2), 149-157. https://doi.org/10.1021/tx0001833.

(19) Wang, D.; Gao, H.; Bandyopadhyay, A.; Wu, A.; Yeh, I.-T.; Chen, Y.; Zou, Y.; Huang, C.; Walter, C. A.; Dong, Q.; Sun, L.-Z. Pubertal Bisphenol A Exposure Alters Murine Mammary Stem Cell Function Leading to Early Neoplasia in Regenerated Glands. Cancer Prev. Res. (Phila. Pa.) 2014, 7 (4), 445-455. https://doi.org/10.1158/1940-6207.CAPR-13-0260.

(20) Mu, X.; Huang, Y.; Li, X.; Lei, Y.; Teng, M.; Li, X.; Wang, C.; Li, Y. Developmental Effects and Estrogenicity of Bisphenol A Alternatives in a Zebrafish Embryo Model. Environ. Sci. Technol. 2018, 52 (5), 3222-3231. https://doi.org/10.1021/acs.est.7b06255. 
Okada H.; Tokunaga T.; Liu X.; Takayanagi S.; Matsushima A.; Shimohigashi Y. Direct Evidence Revealing Structural Elements Essential for the High Binding Ability of Bisphenol A to Human Estrogen-Related Receptor-p. Environ. Health Perspect. 2008, 116 (1), 32-38. https://doi.org/10.1289/ehp.10587.

(22) Sajiki, J.; Miyamoto, F.; Fukata, H.; Mori, C.; Yonekubo, J.; Hayakawa, K. Bisphenol A (BPA) and Its Source in Foods in Japanese Markets. Food Addit. Contam. 2007, 24 (1), 103-112.

https://doi.org/10.1080/02652030600936383.

(23) Caillol, S. Cardanol: A Promising Building Block for Biobased Polymers and Additives. Curr. Opin. Green Sustain. Chem. 2018, 14, 26-32. https://doi.org/10.1016/j.cogsc.2018.05.002.

(24) Hernandez, E. D.; Bassett, A. W.; Sadler, J. M.; La Scala, J. J.; Stanzione, J. F. Synthesis and Characterization of Bio-Based Epoxy Resins Derived from Vanillyl Alcohol. ACS Sustain. Chem. Eng. 2016, 4 (8), 4328-4339. https://doi.org/10.1021/acssuschemeng.6b00835.

(25) Basnet, S.; Otsuka, M.; Sasaki, C.; Asada, C.; Nakamura, Y. Functionalization of the Active Ingredients of Japanese Green Tea (Camellia Sinensis) for the Synthesis of Bio-Based Epoxy Resin. Ind. Crops Prod. 2015, 73, 63-72. https://doi.org/10.1016/j.indcrop.2015.03.091.

(26) Shibata, M.; Nakai, K. Preparation and Properties of Biocomposites Composed of Bio-Based Epoxy Resin, Tannic Acid, and Microfibrillated Cellulose. J. Polym. Sci. Part B Polym. Phys. 2010, 48 (4), 425-433. https://doi.org/10.1002/polb.21903.

(27) Kishi, H.; Fujita, A.; Miyazaki, H.; Matsuda, S.; Murakami, A. Synthesis of Wood-Based Epoxy Resins and Their Mechanical and Adhesive Properties. J. Appl. Polym. Sci. 2006, 102 (3), 2285-2292. https://doi.org/10.1002/app.24433.

(28) Earls, J. D.; White, J. E.; López, L. C.; Lysenko, Z.; Dettloff, M. L.; Null, M. J. Amine-Cured w-Epoxy Fatty Acid Triglycerides: Fundamental Structure-Property Relationships. Polymer 2007, 48 (3), 712-719. https://doi.org/10.1016/j.polymer.2006.11.060.

(29) Decostanzi, M.; Lomège, J.; Ecochard, Y.; Mora, A.-S.; Negrell, C.; Caillol, S. Fatty Acid-Based Cross-Linkable Polymethacrylate Coatings. Prog. Org. Coat. 2018, 124, 147-157.

https://doi.org/10.1016/j.porgcoat.2018.08.001.

(30) Ferdosian, F.; Yuan, Z.; Anderson, M.; Xu, C. (Charles). Sustainable Lignin-Based Epoxy Resins Cured with Aromatic and Aliphatic Amine Curing Agents: Curing Kinetics and Thermal Properties. Thermochim. Acta 2015, 618, 48-55. https://doi.org/10.1016/j.tca.2015.09.012.

(31) Hirose, S.; Hatakeyama, T.; Hatakeyama, H. Synthesis and Thermal Properties of Epoxy Resins from EsterCarboxylic Acid Derivative of Alcoholysis Lignin. Macromol. Symp. 2003, 197 (1), 157-170. https://doi.org/10.1002/masy.200350715.

(32) Mousavioun, P.; Doherty, W. O. S. Chemical and Thermal Properties of Fractionated Bagasse Soda Lignin. Ind. Crops Prod. 2010, 31 (1), 52-58. https://doi.org/10.1016/j.indcrop.2009.09.001.

(33) Huang, Y.-B.; Fu, Y. Hydrolysis of Cellulose to Glucose by Solid Acid Catalysts. Green Chem. 2013, 15 (5), 1095-1111. https://doi.org/10.1039/C3GC40136G.

(34) Pang, J.; Wang, A.; Zheng, M.; Zhang, T. Hydrolysis of Cellulose into Glucose over Carbons Sulfonated at Elevated Temperatures. Chem. Commun. 2010, 46 (37), 6935-6937. https://doi.org/10.1039/C0CC02014A.

(35) Onda, A.; Ochi, T.; Yanagisawa, K. Selective Hydrolysis of Cellulose into Glucose over Solid Acid Catalysts. Green Chem. 2008, 10 (10), 1033-1037. https://doi.org/10.1039/B808471H.

(36) Jacobsen, S. E.; Wyman, C. E. Xylose Monomer and Oligomer Yields for Uncatalyzed Hydrolysis of Sugarcane Bagasse Hemicellulose at Varying Solids Concentration. Ind. Eng. Chem. Res. 2002, 41 (6), 1454-1461. https://doi.org/10.1021/ie001025+.

(37) Zhang, L.; Xi, G.; Chen, Z.; Qi, Z.; Wang, X. Enhanced Formation of 5-HMF from Glucose Using a Highly Selective and Stable SAPO-34 Catalyst. Chem. Eng. J. 2017, 307, 877-883. https://doi.org/10.1016/j.cej.2016.09.003.

(38) Huang, F.; Su, Y.; Tao, Y.; Sun, W.; Wang, W. Preparation of 5-Hydroxymethylfurfural from Glucose Catalyzed by Silica-Supported Phosphotungstic Acid Heterogeneous Catalyst. Fuel 2018, 226, 417-422. https://doi.org/10.1016/j.fuel.2018.03.193.

(39) Qi, X.; Watanabe, M.; Aida, T. M.; Smith, R. L. Catalytical Conversion of Fructose and Glucose into 5Hydroxymethylfurfural in Hot Compressed Water by Microwave Heating. Catal. Commun. 2008, 9 (13), 2244-2249. https://doi.org/10.1016/j.catcom.2008.04.025.

(40) van Putten, R.-J.; van der Waal, J. C.; de Jong, E.; Rasrendra, C. B.; Heeres, H. J.; de Vries, J. G. Hydroxymethylfurfural, A Versatile Platform Chemical Made from Renewable Resources. Chem. Rev. 2013, 113 (3), 1499-1597. https://doi.org/10.1021/cr300182k. 
(41) Moreau, C.; Durand, R.; Peyron, D.; Duhamet, J.; Rivalier, P. Selective Preparation of Furfural from Xylose over Microporous Solid Acid Catalysts. Ind. Crops Prod. 1998, 7 (2), 95-99. https://doi.org/10.1016/S09266690(97)00037-X.

(42) Shi, X.; Wu, Y.; Yi, H.; Rui, G.; Li, P.; Yang, M.; Wang, G. Selective Preparation of Furfural from Xylose over Sulfonic Acid Functionalized Mesoporous Sba-15 Materials. Energies 2011, 4 (4), 669-684. https://doi.org/10.3390/en4040669.

(43) Lam, E.; Chong, J. H.; Majid, E.; Liu, Y.; Hrapovic, S.; Leung, A. C. W.; Luong, J. H. T. Carbocatalytic Dehydration of Xylose to Furfural in Water. Carbon 2012, 50 (3), 1033-1043.

https://doi.org/10.1016/j.carbon.2011.10.007.

(44) Mariscal, R.; Maireles-Torres, P.; Ojeda, M.; Sádaba, I.; Granados, M. L. Furfural: A Renewable and Versatile Platform Molecule for the Synthesis of Chemicals and Fuels. Energy Environ. Sci. 2016, 9 (4), 1144-1189. https://doi.org/10.1039/C5EE02666K.

(45) Delbecq, F.; Wang, Y.; Muralidhara, A.; El Ouardi, K.; Marlair, G.; Len, C. Hydrolysis of Hemicellulose and Derivatives-A Review of Recent Advances in the Production of Furfural. Front. Chem. 2018, 6. https://doi.org/10.3389/fchem.2018.00146.

(46) Cho, J. K.; Lee, J.-S.; Jeong, J.; Kim, B.; Kim, B.; Kim, S.; Shin, S.; Kim, H.-J.; Lee, S.-H. Synthesis of Carbohydrate Biomass-Based Furanic Compounds Bearing Epoxide End Group(s) and Evaluation of Their Feasibility as Adhesives. J. Adhes. Sci. Technol. 2013, 27 (18-19), 2127-2138.

https://doi.org/10.1080/01694243.2012.697700.

(47) Li, X.; Jia, P.; Wang, T. Furfural: A Promising Platform Compound for Sustainable Production of C4 and C5 Chemicals. ACS Catal. 2016, 6 (11), 7621-7640. https://doi.org/10.1021/acscatal.6b01838.

(48) Zhang, D.; Dumont, M.-J. Advances in Polymer Precursors and Bio-Based Polymers Synthesized from 5Hydroxymethylfurfural. J. Polym. Sci. Part Polym. Chem. 2017, 55 (9), 1478-1492.

https://doi.org/10.1002/pola.28527.

(49) Thuy Pham, T. P.; Cho, C.-W.; Yun, Y.-S. Environmental Fate and Toxicity of lonic Liquids: A Review. Water Res. 2010, 44 (2), 352-372. https://doi.org/10.1016/j.watres.2009.09.030.

(50) K. Rihko-Struckmann, L.; Oluyinka, O.; Sahni, A.; McBride, K.; Fachet, M.; Ludwig, K.; Sundmacher, K. Transformation of Remnant Algal Biomass to 5-HMF and Levulinic Acid: Influence of a Biphasic Solvent System. RSC Adv. 2020, 10 (42), 24753-24763. https://doi.org/10.1039/D0RA02784G.

(51) Dutta, S.; De, S.; Saha, B. Advances in Biomass Transformation to 5-Hydroxymethylfurfural and Mechanistic Aspects. Biomass Bioenergy 2013, 55, 355-369. https://doi.org/10.1016/j.biombioe.2013.02.008.

(52) Kuster, B. F. M. 5-Hydroxymethylfurfural (HMF). A Review Focussing on Its Manufacture. Starch - Stärke 1990, 42 (8), 314-321. https://doi.org/10.1002/star.19900420808.

(53) Enomoto, K.; Hosoya, T.; Miyafuji, H. High-Yield Production of 5-Hydroxymethylfurfural from d-Fructose, dGlucose, and Cellulose by Its in Situ Removal from the Reaction System. Cellulose 2018, 25 (4), 2249-2257. https://doi.org/10.1007/s10570-018-1717-3.

(54) Menegazzo, F.; Ghedini, E.; Signoretto, M. 5-Hydroxymethylfurfural (HMF) Production from Real Biomasses. Molecules 2018, 23 (9), 2201. https://doi.org/10.3390/molecules23092201.

(55) De Souza, R. L.; Yu, H.; Rataboul, F.; Essayem, N. 5-Hydroxymethylfurfural (5-HMF) Production from Hexoses: Limits of Heterogeneous Catalysis in Hydrothermal Conditions and Potential of Concentrated Aqueous Organic Acids as Reactive Solvent System. Challenges 2012, 3 (2), 212-232. https://doi.org/10.3390/challe3020212.

(56) Kougioumtzis, M. A.; Marianou, A.; Atsonios, K.; Michailof, C.; Nikolopoulos, N.; Koukouzas, N.; Triantafyllidis, K.; Lappas, A.; Kakaras, E. Production of 5-HMF from Cellulosic Biomass: Experimental Results and Integrated Process Simulation. Waste Biomass Valorization 2018, 9 (12), 2433-2445. https://doi.org/10.1007/s12649-018-0267-0.

(57) de Jong, E.; Dam, M. A.; Sipos, L.; Gruter, G.-J. M. Furandicarboxylic Acid (FDCA), A Versatile Building Block for a Very Interesting Class of Polyesters. In Biobased Monomers, Polymers, and Materials; ACS Symposium Series; American Chemical Society, 2012; Vol. 1105, pp 1-13. https://doi.org/10.1021/bk-2012-1105.ch001. Jia, Z.; Wang, J.; Sun, L.; Zhu, J.; Liu, X. Fully Bio-Based Polyesters Derived from 2,5-Furandicarboxylic Acid (2,5-FDCA) and Dodecanedioic Acid (DDCA): From Semicrystalline Thermoplastic to Amorphous Elastomer. J. Appl. Polym. Sci. 2018, 135 (14), 46076. https://doi.org/10.1002/app.46076.

(59) Tsanaktsis, V.; Terzopoulou, Z.; Nerantzaki, M.; Papageorgiou, G. Z.; Bikiaris, D. N. New Poly(Pentylene Furanoate) and Poly(Heptylene Furanoate) Sustainable Polyesters from Diols with Odd Methylene Groups. Mater. Lett. 2016, 178, 64-67. https://doi.org/10.1016/j.matlet.2016.04.183. 
(60) Thiyagarajan, S.; Vogelzang, W.; Knoop, R. J. I.; E. Frissen, A.; Haveren, J. van; Es, D. S. van. Biobased Furandicarboxylic Acids (FDCAs): Effects of Isomeric Substitution on Polyester Synthesis and Properties. Green Chem. 2014, 16 (4), 1957-1966. https://doi.org/10.1039/C3GC42184H.

(61) Sousa, A. F.; Vilela, C.; Fonseca, A. C.; Matos, M.; Freire, C. S. R.; Gruter, G.-J. M.; Coelho, J. F. J.; Silvestre, A. J. D. Biobased Polyesters and Other Polymers from 2,5-Furandicarboxylic Acid: A Tribute to Furan Excellency. Polym. Chem. 2015, 6 (33), 5961-5983. https://doi.org/10.1039/C5PY00686D.

(62) Luo, K.; Wang, Y.; Yu, J.; Zhu, J.; Hu, Z. Semi-Bio-Based Aromatic Polyamides from 2,5-Furandicarboxylic Acid: Toward High-Performance Polymers from Renewable Resources. RSC Adv. 2016, 6 (90), 87013-87020. https://doi.org/10.1039/C6RA15797A.

(63) Cousin, T.; Galy, J.; Rousseau, A.; Dupuy, J. Synthesis and Properties of Polyamides from 2,5Furandicarboxylic Acid. J. Appl. Polym. Sci. 2018, 135 (8), 45901. https://doi.org/10.1002/app.45901.

(64) Jiang, Y.; Maniar, D.; J. Woortman, A. J.; Loos, K. Enzymatic Synthesis of 2,5-Furandicarboxylic Acid-Based Semi-Aromatic Polyamides: Enzymatic Polymerization Kinetics, Effect of Diamine Chain Length and Thermal Properties. RSC Adv. 2016, 6 (72), 67941-67953. https://doi.org/10.1039/C6RA14585J.

(65) Winnacker, M.; Rieger, B. Biobased Polyamides: Recent Advances in Basic and Applied Research. Macromol. Rapid Commun. 2016, 37 (17), 1391-1413. https://doi.org/10.1002/marc.201600181.

(66) Huang, W.; Hu, X.; Zhai, J.; Zhu, N.; Guo, K. Biorenewable Furan-Containing Polyamides. Mater. Today Sustain. 2020, 10, 100049. https://doi.org/10.1016/j.mtsust.2020.100049.

(67) Delbecq, F.; Len, C. Recent Advances in the Microwave-Assisted Production of Hydroxymethylfurfural by Hydrolysis of Cellulose Derivatives-A Review. Molecules 2018, 23 (8), 1973.

https://doi.org/10.3390/molecules23081973.

(68) Mascal, M. 5-(Chloromethyl)Furfural Is the New HMF: Functionally Equivalent But More Practical in Terms of Its Production From Biomass. ChemSusChem 2015, 8 (20), 3391-3395.

https://doi.org/10.1002/cssc.201500940.

(69) Zhao, D.; Su, T.; Wang, Y.; Varma, R. S.; Len, C. Recent Advances in Catalytic Oxidation of 5Hydroxymethylfurfural. Mol. Catal. 2020, 495, 111133. https://doi.org/10.1016/j.mcat.2020.111133.

(70) Xia, H.; Xu, S.; Hu, H.; An, J.; Li, C. Efficient Conversion of 5-Hydroxymethylfurfural to High-Value Chemicals by Chemo- and Bio-Catalysis. RSC Adv. 2018, 8 (54), 30875-30886. https://doi.org/10.1039/C8RA05308A.

(71) Do, P. T. M.; McAtee, J. R.; Watson, D. A.; Lobo, R. F. Elucidation of Diels-Alder Reaction Network of 2,5Dimethylfuran and Ethylene on HY Zeolite Catalyst. ACS Catal. 2013, 3 (1), 41-46. https://doi.org/10.1021/cs300673b.

(72) Spekreijse, J.; Lammens, T.; Parisi, C.; Ronzon, T.; Vis, M. Insights into the European Market for Bio-Based Chemicals Analysis Based on 10 Key Product Categories; Luxembourg, 2019.

(73) Carole, T. M.; Pellegrino, J.; Paster, M. D. Opportunities in the Industrial Biobased Products Industry. In Proceedings of the Twenty-Fifth Symposium on Biotechnology for Fuels and Chemicals Held May 4-7, 2003, in Breckenridge, CO; Finkelstein, M., McMillan, J. D., Davison, B. H., Evans, B., Eds.; Biotechnology for Fuels and Chemicals; Humana Press: Totowa, NJ, 2004; pp 871-885. https://doi.org/10.1007/978-1-59259-8373_71.

(74) Álvarez-Chávez, C. R.; Edwards, S.; Moure-Eraso, R.; Geiser, K. Sustainability of Bio-Based Plastics: General Comparative Analysis and Recommendations for Improvement. J. Clean. Prod. 2012, 23 (1), 47-56. https://doi.org/10.1016/j.jclepro.2011.10.003.

(75) Salimon, J.; Salih, N.; Yousif, E. Industrial Development and Applications of Plant Oils and Their Biobased Oleochemicals. Arab. J. Chem. 2012, 5 (2), 135-145. https://doi.org/10.1016/j.arabjc.2010.08.007.

(76) Sudesh, K.; Iwata, T. Sustainability of Biobased and Biodegradable Plastics. CLEAN - Soil Air Water 2008, 36 (5-6), 433-442. https://doi.org/10.1002/clen.200700183.

(77) Fache, M.; Viola, A.; Auvergne, R.; Boutevin, B.; Caillol, S. Biobased Epoxy Thermosets from Vanillin-Derived Oligomers. Eur. Polym. J. 2015, 68, 526-535. https://doi.org/10.1016/j.eurpolymj.2015.03.048.

(78) Decostanzi, M.; Auvergne, R.; Boutevin, B.; Caillol, S. Biobased Phenol and Furan Derivative Coupling for the Synthesis of Functional Monomers. Green Chem. 2019, 21 (4), 724-747. https://doi.org/10.1039/C8GC03541E.

(79) Voirin, C.; Caillol, S.; V. Sadavarte, N.; V. Tawade, B.; Boutevin, B.; P. Wadgaonkar, P. Functionalization of Cardanol: Towards Biobased Polymers and Additives. Polym. Chem. 2014, 5 (9), 3142-3162.

https://doi.org/10.1039/C3PY01194A. 
(80) Herbst, A.; Janiak, C. Selective Glucose Conversion to 5-Hydroxymethylfurfural (5-HMF) Instead of Levulinic Acid with MIL-101Cr MOF-Derivatives. New J. Chem. 2016, 40 (9), 7958-7967.

https://doi.org/10.1039/C6NJ01399F.

(81) Jiang, M.; Liu, Q.; Zhang, Q.; Ye, C.; Zhou, G. A Series of Furan-Aromatic Polyesters Synthesized via Direct Esterification Method Based on Renewable Resources. J. Polym. Sci. Part Polym. Chem. 2012, 50 (5), 10261036. https://doi.org/10.1002/pola.25859.

(82) Jiang, L.; Gonzalez-Diaz, A.; Ling-Chin, J.; Malik, A.; Roskilly, A. P.; Smallbone, A. J. PEF Plastic Synthesized from Industrial Carbon Dioxide and Biowaste. Nat. Sustain. 2020, 3 (9), 761-767.

https://doi.org/10.1038/s41893-020-0549-y.

(83) Rosenboom, J.-G.; Hohl, D. K.; Fleckenstein, P.; Storti, G.; Morbidelli, M. Bottle-Grade Polyethylene Furanoate from Ring-Opening Polymerisation of Cyclic Oligomers. Nat. Commun. 2018, 9 (1), 2701. https://doi.org/10.1038/s41467-018-05147-y.

(84) Hu, F.; La Scala, J. J.; Sadler, J. M.; Palmese, G. R. Synthesis and Characterization of Thermosetting FuranBased Epoxy Systems. Macromolecules 2014, 47 (10), 3332-3342. https://doi.org/10.1021/ma500687t.

(85) Hu, F.; Yadav, S. K.; Scala, J. J. L.; Sadler, J. M.; Palmese, G. R. Preparation and Characterization of Fully Furan-Based Renewable Thermosetting Epoxy-Amine Systems. Macromol. Chem. Phys. 2015, 216 (13), 1441-1446. https://doi.org/10.1002/macp.201500142.

(86) Holfinger, M. S.; Conner, A. H.; Holm, D. R.; Hill, C. G. Synthesis of Difurfuryl Diamines by the Acidic Condensation of Furfurylamine with Aldehydes and Their Mechanism of Formation. J. Org. Chem. 1995, 60 (6), 1595-1598. https://doi.org/10.1021/jo00111a017.

(87) Conner, A. H.; Holfinger, M. S.; Jr, C. G. H.; McKillip, W. J.; Reimann, R. H. One Step Method for the Preparation of Difurfuryl Diamines. US5292903A, March 8, 1994.

(88) Skouta, M.; Lesimple, A.; Bigot, Y. L.; Delmas, M. New Method for the Synthesis of Difuranic Diamines and Tetrafuranic Tetra-Amines. Synth. Commun. 1994, 24 (18), 2571-2576. https://doi.org/10.1080/00397919408010569.

(89) Deng, J.; Liu, X.; Li, C.; Jiang, Y.; Zhu, J. Synthesis and Properties of a Bio-Based Epoxy Resin from 2,5Furandicarboxylic Acid (FDCA). RSC Adv. 2015, 5 (21), 15930-15939. https://doi.org/10.1039/C5RA00242G.

(90) Yang, J. H.; Srikanth, A.; Jang, C.; Abrams, C. F. Relationships between Molecular Structure and Thermomechanical Properties of Bio-Based Thermosetting Polymers. J. Polym. Sci. Part B Polym. Phys. 2017, 55 (3), 285-292. https://doi.org/10.1002/polb.24270.

(91) Meng, J.; Zeng, Y.; Chen, P.; Zhang, J.; Yao, C.; Fang, Z.; Ouyang, P.; Guo, K. Flame Retardancy and Mechanical Properties of Bio-Based Furan Epoxy Resins with High Crosslink Density. Macromol. Mater. Eng. 2020, 305 (1), 1900587. https://doi.org/10.1002/mame.201900587.

(92) Marotta, A.; Faggio, N.; Ambrogi, V.; Cerruti, P.; Gentile, G.; Mija, A. Curing Behavior and Properties of Sustainable Furan-Based Epoxy/Anhydride Resins. Biomacromolecules 2019, 20 (10), 3831-3841. https://doi.org/10.1021/acs.biomac.9b00919.

(93) Marotta, A.; Faggio, N.; Ambrogi, V.; Mija, A.; Gentile, G.; Cerruti, P. Biobased Furan-Based Epoxy/TiO2 Nanocomposites for the Preparation of Coatings with Improved Chemical Resistance. Chem. Eng. J. 2021, 406, 127107. https://doi.org/10.1016/j.cej.2020.127107.

(94) Shen, X.; Liu, X.; Dai, J.; Liu, Y.; Zhang, Y.; Zhu, J. How Does the Hydrogen Bonding Interaction Influence the Properties of Furan-Based Epoxy Resins. Ind. Eng. Chem. Res. 2017, 56 (38), 10929-10938. https://doi.org/10.1021/acs.iecr.7b02901.

(95) Holladay, J. E.; White, J. F.; Bozell, J. J.; Johnson, D. Top Value-Added Chemicals from Biomass - Volume IIResults of Screening for Potential Candidates from Biorefinery Lignin; PNNL-16983; Pacific Northwest National Lab. (PNNL), Richland, WA (United States), 2007. https://doi.org/10.2172/921839.

(96) Zhao, D.; Rodriguez-Padron, D.; Triantafyllidis, K. S.; Wang, Y.; Luque, R.; Len, C. Microwave-Assisted Oxidation of Hydroxymethyl Furfural to Added-Value Compounds over a Ruthenium-Based Catalyst. ACS Sustain. Chem. Eng. 2020, 8 (8), 3091-3102. https://doi.org/10.1021/acssuschemeng.9b05656.

(97) Liu, Y.; Zhao, J.; Peng, Y.; Luo, J.; Cao, L.; Liu, X. Comparative Study on the Properties of Epoxy Derived from Aromatic and Heteroaromatic Compounds: The Role of Hydrogen Bonding. Ind. Eng. Chem. Res. 2020, 59 (5), 1914-1924. https://doi.org/10.1021/acs.iecr.9b05904.

(98) Meng, J.; Zeng, Y.; Chen, P.; Zhang, J.; Yao, C.; Fang, Z.; Guo, K. New Ultrastiff Bio-Furan Epoxy Networks with High Tg: Facile Synthesis to Excellent Properties. Eur. Polym. J. 2019, 121, 109292.

https://doi.org/10.1016/j.eurpolymj.2019.109292. 
(99) Marotta, A.; Ambrogi, V.; Cerruti, P.; Mija, A. Green Approaches in the Synthesis of Furan-Based Diepoxy Monomers. RSC Adv. 2018, 8 (29), 16330-16335. https://doi.org/10.1039/C8RA02739K.

(100) Aouf, C.; Nouailhas, H.; Fache, M.; Caillol, S.; Boutevin, B.; Fulcrand, H. Multi-Functionalization of Gallic Acid. Synthesis of a Novel Bio-Based Epoxy Resin. Eur. Polym. J. 2013, 49 (6), 1185-1195.

https://doi.org/10.1016/j.eurpolymj.2012.11.025.

(101) Nameer, S.; Larsen, D. B.; Duus, J. Ø.; Daugaard, A. E.; Johansson, M. Biobased Cationically Polymerizable Epoxy Thermosets from Furan and Fatty Acid Derivatives. ACS Sustain. Chem. Eng. 2018, 6 (7), 9442-9450. https://doi.org/10.1021/acssuschemeng.8b01817.

(102) Zhang, L.; Luo, X.; Qin, Y.; Li, Y. A Novel 2,5-Furandicarboxylic Acid-Based Bis(Cyclic Carbonate) for the Synthesis of Biobased Non-Isocyanate Polyurethanes. RSC Adv. 2017, 7 (1), 37-46. https://doi.org/10.1039/C6RA25045A.

(103) Gaitonde, V.; Lee, K.; Kirschbaum, K.; Sucheck, S. J. Bio-Based Bisfuran: Synthesis, Crystal Structure, and Low Molecular Weight Amorphous Polyester. Tetrahedron Lett. 2014, 55 (30), 4141-4145. https://doi.org/10.1016/j.tetlet.2014.05.043.

(104) Meng, J.; Zeng, Y.; Zhu, G.; Zhang, J.; Chen, P.; Cheng, Y.; Fang, Z.; Guo, K. Sustainable Bio-Based Furan Epoxy Resin with Flame Retardancy. Polym. Chem. 2019, 10 (19), 2370-2375. https://doi.org/10.1039/C9PY00202B.

(105) Casanova, O.; Iborra, S.; Corma, A. Chemicals from Biomass: Etherification of 5-Hydroxymethyl-2-Furfural (HMF) into 5,5'(Oxy-Bis(Methylene))Bis-2-Furfural (OBMF) with Solid Catalysts. J. Catal. 2010, 275 (2), 236242. https://doi.org/10.1016/j.jcat.2010.08.002.

(106) Balakrishnan, M.; Sacia, E. R.; Bell, A. T. Etherification and Reductive Etherification of 5(Hydroxymethyl)Furfural: 5-(Alkoxymethyl)Furfurals and 2,5-Bis(Alkoxymethyl)Furans as Potential Bio-Diesel Candidates. Green Chem. 2012, 14 (6), 1626-1634. https://doi.org/10.1039/C2GC35102A.

(107) Chundury, D.; Szmant, H. H. Preparation of Polymeric Building Blocks from 5-Hydroxymethyl- and 5Chloromethylfurfuraldehyde. Ind. Eng. Chem. Prod. Res. Dev. 1981, 20 (1), 158-163. https://doi.org/10.1021/i300001a022.

(108) Xu, Z.; Yan, P.; Liu, K.; Wan, L.; Xu, W.; Li, H.; Liu, X.; Zhang, Z. C. Synthesis of Bis(Hydroxylmethylfurfuryl)Amine Monomers from 5-Hydroxymethylfurfural. ChemSusChem 2016, 9 (11), 1255-1258. https://doi.org/10.1002/cssc.201600122.

(109) Miao, J.-T.; Yuan, L.; Guan, Q.; Liang, G.; Gu, A. Biobased Heat Resistant Epoxy Resin with Extremely High Biomass Content from 2,5-Furandicarboxylic Acid and Eugenol. ACS Sustain. Chem. Eng. 2017, 5 (8), 70037011. https://doi.org/10.1021/acssuschemeng.7b01222.

(110) Gu, A.; Miao, J.; Liang, G.; Yuan, L. Biomass-Based Epoxy Resin and Preparation Method Thereof. US20200062888A1, February 27, 2020.

(111) Chen, C. H.; Gu, Z. C.; Tsai, Y. L.; Jeng, R. J.; Lin, C. H. Identification of the Reaction Mechanism between Phenyl Methacrylate and Epoxy and Its Application in Preparing Low-Dielectric Epoxy Thermosets with Flexibility. Polymer 2018, 140, 225-232. https://doi.org/10.1016/j.polymer.2018.02.045.

(112) Park, H.-W.; Toan, M.; Kim, H.-J.; Lee, J.-H.; Shin, S. Renewable Epoxy Thermosets with Extremely High Biomass Content from Furan Derivatives and Their Flame Retardancy. J. Ind. Eng. Chem. 2020, 92, 184-190. https://doi.org/10.1016/j.jiec.2020.09.003.

(113) Chougrani, K.; Boutevin, B.; David, G.; Boutevin, G. New N,N-Amino-Diphosphonate-Containing Methacrylic Derivatives, Their Syntheses and Radical Copolymerizations with MMA. Eur. Polym. J. 2008, 44 (6), 17711781. https://doi.org/10.1016/j.eurpolymj.2008.03.009.

(114) Tian, Q.; Rong, M. Z.; Zhang, M. Q.; Yuan, Y. C. Synthesis and Characterization of Epoxy with Improved Thermal Remendability Based on Diels-Alder Reaction. Polym. Int. 2010, 59 (10), 1339-1345. https://doi.org/10.1002/pi.2872. 


\section{For Table of Contents Use Only}

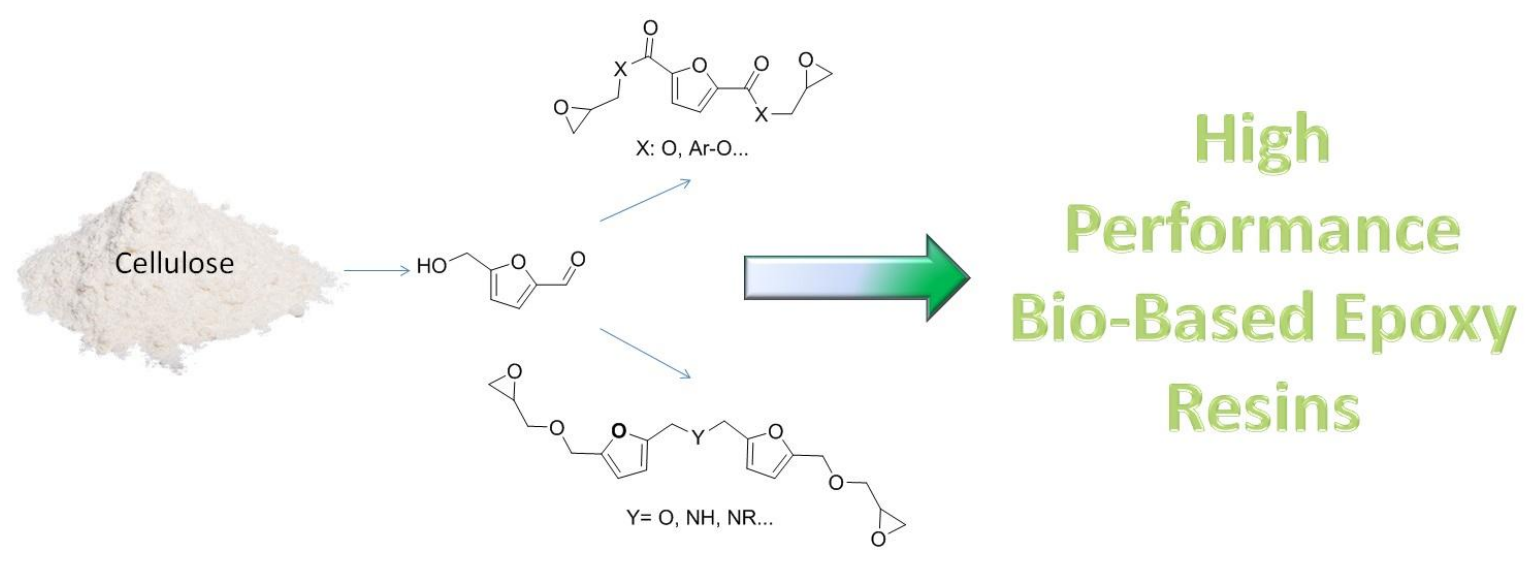

This review reports synthetic strategies of epoxy monomers from biosourced 2-furfural, 5(hydroxymethyl)furfural, and describes the resulting resins as well as their thermal and mechanical properties, compared to their fossil fuel analogues. 